\title{
Adaptive Trade-offs Towards the Last Glacial Maximum in North-Western Europe: a Multidisciplinary View from Walou Cave
}

\section{Luc Moreau, et al. [full author details at the end of the article]}

Accepted: 15 January 2021 /Published online: 16 April 2021

(C) The Author(s) 2021

\begin{abstract}
The impact of deteriorating climatic conditions on variability in the archaeological record towards the Last Glacial Maximum (LGM) remains uncertain. Partly as a result of poor-quality data, previous studies on Upper Palaeolithic (UP) societies of NorthWestern Europe prior to the LGM have focused on techno-typological traditions and diversification to outline the diachronic processes through which assemblage composition changed. This study addresses the adaptive trade-offs brought about by the general climatic downturn towards the LGM in North-Western Europe, by investigating the impact of local climate and habitat characteristics on the behavioural variability that characterises Gravettian technological organisation compared to the previous Aurignacian, based on two assemblages from Walou Cave, Belgium. This site is one of the rare well-stratified sites in North-Western Europe with evidence for multiple occupation events accompanied by a fine-grained palaeoenvironmental record. We use a combination of analytical techniques (AMS, LA-ICP-MS and ZooMS) to evaluate questions about hunter-gatherer adaptations. Faunal remains at Walou Cave mirror the faunal diversity documented at numerous other Aurignacian and Gravettian sites in the broader European context, which is similar between both periods. The overall picture presented here, using multiple lines of evidence, is not entirely clear; nonetheless, the results suggest that Gravettian technologies are unlikely to solely be a product of heightened risk in relation to a significant reshuffling of food resources compared to the previous Aurignacian. Future research of the factors structuring assemblage variability prior to the LGM will have to assess whether Aurignacian and Gravettian technologies indeed offer no relative material advantage over one another, a phenomenon called 'technological equivalence'.
\end{abstract}

Keywords Aurignacian · Gravettian · Technological organisation · Faunal diversity · Human ecology

\section{Introduction}

In Europe, the period between 33 and 20 ka uncal BP experienced the growth of global ice-sheet and mountain-glacier extents towards the Last Glacial Maximum (LGM) 
(Clark et al. 2009), seeing a series of profound behavioural changes in human evolutionary history. Important new features of the period include the earliest unambiguous Upper Palaeolithic (UP) burials in Europe (Pettitt 2011) and the appearance of extensive and intensively used multipurpose open-air sites, occasionally in association with burials, indicating patterns of increased residential stability as a result of repeated occupations of seasonal or multiseasonal character (Antl-Weiser et al. 2010; Lacarrière et al. 2015; Paris et al. 2017; Simon et al. 2014; Svoboda et al. 2000, 2016). The timing and nature of these new features roughly coincide with the socio-cultural change from the Aurignacian to Gravettian, two major techno-complexes of the UP prior to the LGM characterised by different technological systems. Whilst North-Western Europe was largely dominated by open, treeless vegetation during the Last Glacial (Fletcher et al. 2010), the occasional existence of temperate 'cryptic refugia' has been hypothesised, characterised by higher biodiversity than in the surrounding areas (Stewart et al. 2010).

A significant behavioural shift from the Aurignacian to the Gravettian concerns the organisation of lithic technological systems, particularly with regard to the production of blades and bladelets (Bodu et al. 2013; Flas 2015; Mevel 2013; Moreau 2010, 2012; Touzé 2018). By comparison with the previous Aurignacian, the laminar technology of the Gravettian period is oriented towards regular and elongated, and to some extent straighter blanks (Klaric 2003, 2013; Lengyel and Chu 2016; Moreau 2010, 2012; Touzé 2018; Touzé et al. 2016). This is not to say that Gravettian lithic technological systems do not exhibit any common features with the previous Aurignacian (see 'Lithic Technology') (Moreau 2012; Moreau and Jöris 2013; Pesesse 2010); however, the Gravettian is generally characterised by a higher investment in debitage surface maintenance, partly resulting in increasingly bidirectional laminar blank production methods using two opposed striking platforms (Klaric 2003, 2013; Lengyel and Chu 2016; Moreau 2010, 2012; Touzé 2018; Touzé et al. 2016). Moreover, it has been claimed that the production of regular blades and bladelets in the Gravettian, together with the manufacture of new artefact forms including standardised backed points and backed bladelets, required an increased reliance on high-quality and, to some extent, more distant raw materials (Féblot-Augustins 1997, 2009; Floss 1994; Morala and Turq 1991). However, raw material use in the Aurignacian of Western and Central Europe is far from being based entirely on local raw materials (Bon et al. 2005; Bordes et al. 2005; Brandl et al. 2015; Caux and Bordes 2016; Moreau and Terberger 2019). The degree of technological planning attested to in the Aurignacian in order to keep individuals supplied with good-quality raw material contradicts the idea of opportunistic patterns of land use prior to the Gravettian.

Despite recent advances in palaeoclimatic reconstructions and ongoing developments in the quality and chronological resolution of archaeological data (Bicho and Cascalheira 2018, and references therein), the impact of changing environmental constraints on Aurignacian and Gravettian assemblage variability towards the LGM remains uncertain. Clearly, the scarcity of Aurignacian and Gravettian assemblages in North-Western Europe with secure chronostratigraphic and palaeoenvironmental contexts is a significant obstacle to our understanding of the impact of environmental change on technological variability. Broadly speaking, two models are commonly used to explain the socio-cultural changes occurring in Europe towards the LGM: 
- Gravettian assemblages are the signature of new, incoming people who brought a unique technological and symbolic package with them, accompanied by a population turnover that led to the replacement of local Aurignacian groups (e.g. Bicho et al. 2017; Garrod 1938; Otte 2013; Sonneville-Bordes 1963; Svoboda 2007).

- Gravettian technologies and symbolic manifestations are the result of an indigenous development of local groups, either in continuity with the Aurignacian, or as the result of acculturation of local Late Middle Palaeolithic industries by incoming Aurignacian groups (e.g. Flas 2000-2001; Klíma 1959; Kozłowski 2015; Otte 1983; Otte and Noiret 2013; Valoch 1981).

A combination of both models suggests local development of the Gravettian out of the Aurignacian, and a concomitant influx of new people, which would at least explain the rapid spread of Gravettian technologies throughout Europe after 30 ka uncal BP (Moreau and Jöris 2013; Kozłowski 2015). Paradoxically, recent aDNA studies (Fu et al. 2016) are compatible with both models as they are unable to quantify the size and geographic origin of the observed genetic input. In fact, whilst clear evidence for some level of population change during the Gravettian period is supported by aDNA evidence (Fu et al. 2016), the existence of a complete turnover and the migration of populations using Gravettian technologies from outside Europe could not be established.

It is important to note that the aforementioned models do not directly address the mechanisms underlying the Aurignacian-Gravettian socio-cultural change. Accordingly, the adaptive trade-offs in the costs and benefits of the different food-getting technologies characterising the Aurignacian and Gravettian are still poorly understood. Partly as a result of poor-quality data, previous studies have focused mainly on outlining the diachronic processes through which Aurignacian and Gravettian technologies changed. It follows that assemblage variability is typically considered to reflect socio-cultural traditions and diversification more than it reflects evolutionary strategies that give actors the optimum return under prevailing ecological and social conditions (Clark 2009).

Walou Cave is among the rare sites in North-Western Europe to have yielded both Aurignacian and Gravettian assemblages with secure chronostratigraphic and palaeoenvironmental control, contextualised with faunal remains (Draily 2011a, b; Draily et al. 2011; Pirson 2011; Pirson et al. 2011a). By investigating the impact of local climate and habitat characteristics on the behavioural variability that characterises Gravettian technological organisation compared to the previous Aurignacian at Walou Cave, this study is a step towards addressing the adaptive trade-offs brought about by the general climatic downturn towards the LGM in North-Western Europe.

This research further examines the proposition that climatic deterioration towards the LGM may have encouraged greater mobility and more extended social networks among Gravettian hunter-gatherers than previous Aurignacian populations to mitigate against the risk of resource failure (Gamble 1999; Svoboda et al. 2000). The important seasonal fluctuations in the distribution and predictability of subsistence resources during the conditions of global cold temperatures towards the LGM may indeed be considered a mechanism for socio-cultural change among UP societies. Increasing group mobility as reflected in the magnitude of lithic raw material procurement ranges on a macro-regional scale has been interpreted as indicative of adaptation to 
environmental conditions, "with the longest moves being recorded in the most exacting environments' (Féblot-Augustins 2009: 26). However, the impact of environmental change on Aurignacian and Gravettian lithic procurement strategies in North-Western Europe is currently too poorly understood.

\section{Research Objectives}

The coincidence of climatic-environmental and cultural change is a powerful incentive to propose causal connections. However, the causal relationship between palaeoenvironmental constraints and concomitant changes in the organisational characteristics of food-getting technologies requires demonstration rather than assumption. Here, we investigate the hypothesis that the technological organisation characterising the Gravettian results from concurrent changes in the natural environment as an adaptive trade-off to more unpredictable environmental conditions towards the LGM. Using Walou Cave as a case study, our research objectives are:

- To reconstruct palaeoenvironmental conditions through time based on interassemblage comparison of Aurignacian and Gravettian faunas. Fluctuations in subsistence resources between the Aurignacian and Gravettian have been assessed through faunal diversity where prey ranking serves as a measure of diet-breadth and intensification. We provide insights into the climate-related environmental conditions at Walou Cave by directly dating osseous artifacts and calibrating the new radiocarbon dates using the IntCal13 calibration curve.

- To characterise Aurignacian and Gravettian osseous and lithic technological organisation in response to faunal diversity and raw material availability. We assess the scale of group mobility and its possible correlation with environmental change by geochemically provenancing non-local flint artefacts. To articulate subsistence strategies and technological organisation, all Aurignacian and Gravettian osseous artefacts from Walou Cave were analysed by means of ZooMS for species identification.

This study presents, for the first time, quantitative data on the complete Gravettian faunal assemblage from Michel Dewez' excavations (1985-1990) (Dewez 1993, 2008). Likewise, inter-assemblage comparison between Aurignacian and Gravettian lithic assemblages at Walou Cave is based on new quantitative data for the complete assemblages.

\section{Regional Setting: Walou Cave}

Evidence of human occupation is abundant across North-Western Europe throughout various periods of the Palaeolithic (Pettitt and White 2012; Pirson et al. 2012). The karstic landscape of the Meuse Valley in the southern part of Belgium constitutes one of North-Western Europe's archaeological hotspots and has a long history of archaeological research (Toussaint and Pirson 2007). Whilst the presence of Aurignacian and Gravettian occupations is attested to at multiple archaeological sites (Fig. 1), most 
Palaeolithic sites of the Meuse Basin were excavated well before modern techniques were developed during the second half of the twentieth century. Accordingly, the chronostratigraphic framework for the UP in Belgium prior to the LGM is still far from satisfactory (Pirson et al. 2012). Clearly, the coarse-grained chronology for most of the cave deposits, possible biases by old excavation techniques, and potential traces of contamination by reworked industries, represent major obstacles for investigating the nature and timing of behavioural variability prior to the LGM in this region.

Backing up behavioural reconstructions with regional high-resolution palaeoenvironmental records is key given the complexity of regional ecosystem responses to hemispheric and global processes of palaeoclimate change recorded in ice or marine cores (e.g. Müller et al. 2011; Beresford-Jones et al. 2011). Walou Cave is one of the rare well-stratified sites in North-Western Europe with multiple occupation events combined with a fine-grained palaeoenvironmental record that provides multiple proxies for examining the impact of Pleniglacial dynamics on hunter-gatherer adaptive trade-offs at a regional scale.

Excavated in the framework of multidisciplinary research projects, Walou Cave $\left(50^{\circ}\right.$ $57^{\prime} \mathrm{N} ; 5^{\circ} 71^{\prime} \mathrm{E}$ ) has yielded the most complete and best documented Late Quaternary sequence available out of all the Belgian caves, together with Scladina Cave (Pirson et al. 2012). Discovered in the 1960s, the site has been the subject of two multidisciplinary archaeological excavations, first from 1985 to 1990 (Dewez 1993, 2008) and then from 1996 to 2004 (Draily 2011a, b; Draily et al. 2011; Pirson et al. 2011a).

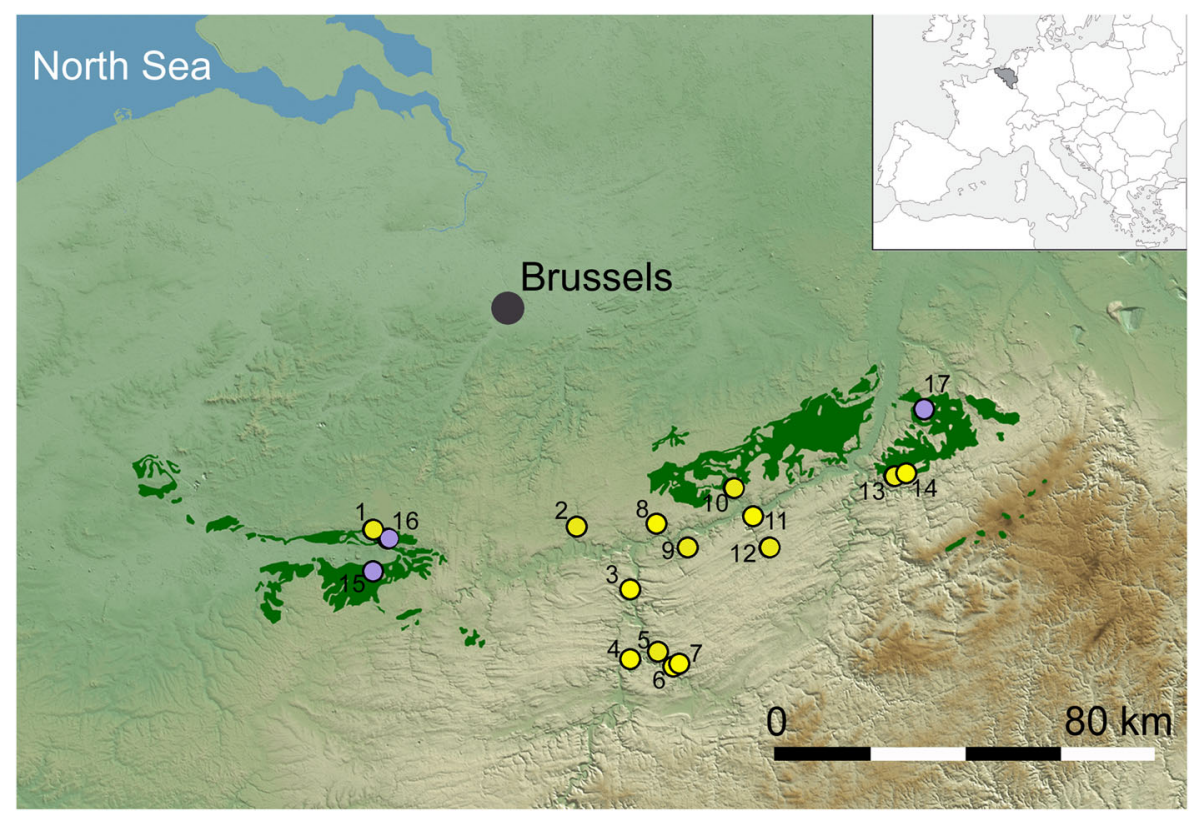

Fig. 1 Physical map showing the distribution of Upper Cretaceous flint (dark green areas) in the territory of Belgium. Yellow dots correspond to Aurignacian and Gravettian archaeological sites: 1, Maisières-Canal; 2, Spy; 3, Trou du Sureau; 4, Trou du Diable; 5, Magrite; 6, Trou Reuviau; 7, Trou du Renard; 8, Grottes de la Princesse et du Prince; 9, Goyet; 10, Huccorgne; 11, Grand Abri de Ben-Ahin; 12, Trou Al'Wesse; 13, Walou Cave; 14, Fonds-de-Forêt. Blue dots correspond to flint sources sampled for geochemical analyses; 15 , Harmignies for samples of NO and SP flint; 16, Obourg for samples of OB flint; 17, Haccourt for samples of ZW flint 
Walou Cave's chronostratigraphy spans the late Saalian to the Holocene, including the Eemian, Early Glacial, Lower, Middle and Upper Pleniglacial, as well as the Late Glacial (Fig. 2). The coherence and internal consistency of the chronostratigraphic framework at Walou Cave is supported by combining the climatostratigraphic signature of the sequence with numerous radiometric dating methods (i.e. ${ }^{14} \mathrm{C}, \mathrm{ESR}-\mathrm{U} / \mathrm{Th}, \mathrm{TL}$ ), tephrostratigraphy and clear correlations with the well-studied loess sequences of Middle Belgium (Pirson 2011; Pirson et al. 2006, 2012).

During the 1985-1990 excavations, four major sedimentary units were identified and detailed stratigraphic recording of the upper half of the sequence was carried out solely on the main section of the site (Collcutt 1993; Draily 2011a, b). Subsequent excavation campaigns between 1996 and 2004 recorded standing sections from previous excavations in addition to many new sections (Pirson 2011; Pirson et al. 2011a). The integration of both sets of stratigraphic data (1985-1990 and 1996-2004) resulted in a 12-m sequence divided into ten sedimentary cycles including more than 40 layers (Pirson 2011).

Based on the excavations carried out between 1985 and 1990, Collcutt (1993) defined a succession of members and layers, with the Aurignacian and Gravettian occupations at Walou Cave corresponding to layers C6 and B5, respectively. In Collcutt's stratigraphical nomenclature, subdivisions of the Aurignacian layer (i.e. C6A to $\mathrm{C} 6 \mathrm{E}$ ) have been interpreted in terms of short cycles in relation to variations in sedimentation rate (Collcutt 1993). Later work by Pirson established a new terminology based on cycles and layers (Pirson 2011; Pirson et al. 2011a). Pirson correlated layer CI-1 (excavations 1996-2004) with Collcutt's layer C6 (excavations 1985-1990). Furthermore, Pirson renamed Collcutt's layer B5 into B-5, as he could identify it solely on the main section of the previous excavations (excavations 1985-1990).

Almost no Aurignacian and Gravettian artefacts were recovered during the excavations 1996-2004. In fact, during the more recent excavations only layers C6D and C6E have been observed, whilst the other layers (i.e. C6A, C6B and C6C) seem to have been present inside the cave only and were entirely excavated in the course of the previous fieldwork led by Dewez (Draily 2011a, b). However, Aurignacian artefacts derive mainly from $\mathrm{C} 6 \mathrm{C}$ and $\mathrm{C} 6 \mathrm{D}$, whereas only a few artefacts have been recorded in C6A, C6B and C6E (Dewez 1993).

\section{Palaeoenvironmental Framework}

Geological studies of the standing sections at Walou Cave highlight a number of pronounced climatic signals, particularly those recorded by pedological and sedimentary processes including in situ or reworked palaeosols, cryoturbations, melt water gullies and loess deposition (Pirson 2011; Pirson et al. 2011a). The palaeoclimatic significance of these signals has been reinforced by palynological, anthracological, palaeozoological and magnetic susceptibility data (Damblon et al. 2011; Pirson et al. 2006, 2011a, b, 2012).

At Walou Cave, the Aurignacian assemblage derives from Unit CI-1. The latter corresponds to a humic horizon resulting from pedogenesis, which formed during a period of climatic amelioration ('Walou 9') (Pirson 2011, p. 181). The presence of two generations of speleothems associated with this horizon (Collcutt 1993) further supports the argument of climatic improvement. Palynology confirms the existence of a 
climatic amelioration of interstadial character in CI-1 (zone pollinique 8), pointing to a more or less forested steppe with an increase in humidity (Damblon et al. 2011). Pollen diagrams show a significant quantitative increase of Pinus and Apiaceae pollen grains as well as fern spores. The autochthonous nature of Pinus is indicated by the occurrence of conifer tracheid remains (Damblon et al. 2011).

The faunal assemblage of Unit CI-1 underlines the moderately cold, interstadial character of unit CI-1, which has been interpreted as reflecting open, steppe-like vegetation on the plateau in combination with wetter grasslands and small stands of trees in the valley bottoms (Cordy 1993; Stewart and Parfitt 2011). Bird remains of forest-adapted species including corvids (likely Corvus monedula) and owls (i.e. Asio otus) are also worth mentioning in this context (De Wilde 2011; Pirson 2011, p. 182). The microfauna is dominated by grassland rodents, particularly Arvicola terrestris and Microtus oeconomicus, the latter suggesting humid conditions (Stewart and Parfitt 2011). Moreover, the relatively common presence of mole (Talpa europaea) remains in Unit CI-1 indicates that the soil was not permanently frozen and that it supported a rich invertebrate fauna (Stewart and Parfitt 2011).

The Gravettian occupation at Walou Cave is correlated with Unit B-5. The microfauna composition in B-5 (following Pirson and Draily's stratigraphic nomenclature) mirrors that observed in CI-1, both being indicative of humid conditions as well as open but not necessarily cold conditions (Cordy 1991; Stewart and Parfitt 2011). This, combined with some geological arguments (weathered limestone blocks and possible interstadial pedogenesis), strongly suggests the existence of an interstadial episode in B-5 (Pirson 2011, p. 184). However, the palynological signature of B-5 (zone pollinique 9) reflects non-forested, dry steppic vegetation of stadial character dominated by Cichorioideae, and thus does not support the existence of an interstadial episode in B-5 (Damblon et al. 2011).

Between Unit CI-1 and Unit B-5, a complex history is recorded locally (Pirson et al. 2011a). Unit CI-1 locally underwent cryoturbation and probably solifluction, and it is laterally covered by $\mathrm{Cycle} \mathrm{C} 0$, which points to the onset of cold conditions following the deposition of CI-1. Later on, CI-1 (and probably C0) was affected by gullying from the lowermost part of Cycle B (Unit B-HE).

\section{Lithic Raw Material Use}

In Belgium, exposed lithological strata yielding good-quality Upper Cretaceous flint suitable for stone tool manufacture outcrops mainly on the plains of Middle Belgium along the northern ridge of the Sambre-Meuse fluvial basin, particularly in eastern and western Belgium (Fig. 1) (Felder and Bosch 2000; De Grooth 2011; Miller 2001; Moreau et al. 2016). However, in many places, these deposits are buried below up to several meters of thick Quaternary loess deposits, reaching locally a thickness of c. 15 m (Pirson et al. 2006, 2008, 2012; Haesaerts et al. 2016). Aurignacian and Gravettian groups did not necessarily have access to the same lithic raw materials, given periods of major aeolian sedimentation across Middle Belgium during the Weichselian Late Pleniglacial, with the the so-called Harveng tundra gley dated around $26 \mathrm{ka}$ uncal BP marking the upper boundary of the Weichselian Middle Pleniglacial (Haesaerts et al. 2016). 


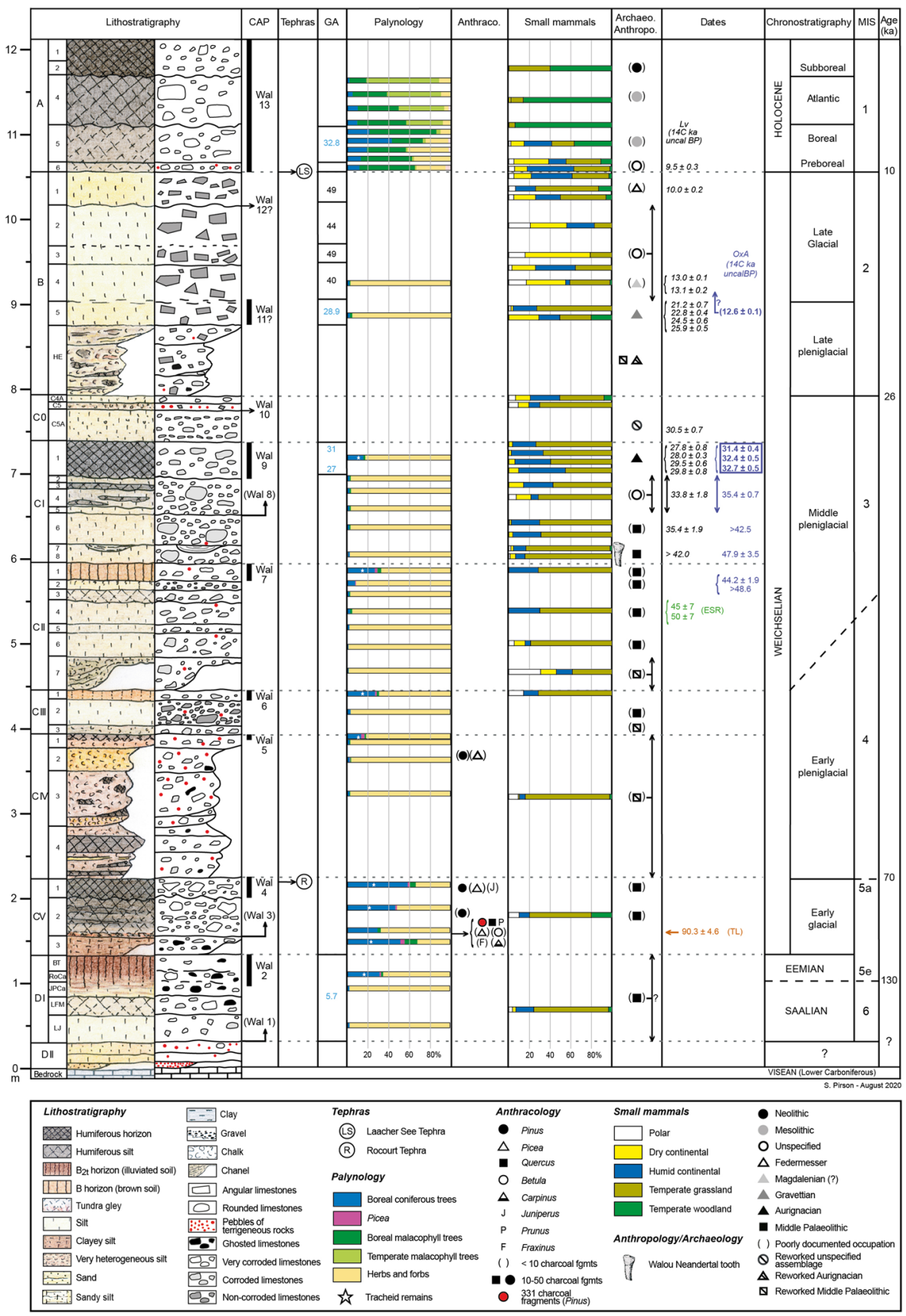

This being said, raw materials do not undergo marked changes in frequency throughout the Aurignacian-Gravettian sequence at Walou Cave. Maastrichtian 'Lanaye flint' is the most commonly used raw material (Draily 2011d), a cryptocrystalline silica-rich sedimentary rock of Upper Cretaceous age, generally occurring in 
Fig. 2 Walou Cave. Stratigraphic sequence with the 13 climatic amelioration phases inferred from the pedosedimentary data (Pirson 2011; Pirson et al. 2011a, b; Draily et al. 2011). Most of the data from cycles A and B are from (Dewez 1993). CAP, climatic amelioration phases; GA, green amphibole content (\%) from heavy minerals of the silt fraction (see Pirson et al. 2011a); Palynology, synthesis of the palynological record (see Damblon et al. 2011); Anthraco., anthracology (Damblon 2011); Small mammals, synthesis of palaeoecological signatures inferred from macrofaunal assemblages (Cordy 1991, 1993; Turmes 1996; Stewart and Parfitt 2011); Archaeo./Anthropo., archaeological assemblages identified in the sequence (see Draily 2011a) and position of the Neanderthal tooth (Toussaint et al. 2017); Dates, the dates mentioned are uncalibrated ${ }^{14} \mathrm{C}$ dates, with the four new radiocarbon determinations in bold blue (see Pirson et al. $2011 \mathrm{~b}$ and this paper; Higham et al. 2014), except for two ESR/U-Th dates on animal teeth (Pirouelle in Draily et al. 2011) and four TL dates on burnt limestone for which the mean is given here (Debenham in Draily et al. 2011); Chronostratigraphy, chronostratigraphic interpretation based on all available disciplines (see Pirson 2011; Pirson et al. 2006, 2011a, b); MIS, proposed correlation with marine oxygen isotopic stages

nodular shapes of very variable size (Felder and Bosch 2000). Potential sources for 'Lanaye flint' at Walou Cave are represented in the sedimentary rocks that compose the Hesbaye region in Belgium and the southern Limburg region in The Netherlands (Felder and Bosch 2000; De Grooth 2011). This suggests that most of the raw materials exploited in the Aurignacian and Gravettian occupations of Walou Cave derive from local sources within a maximum range of c. 15-20 km. Moreover, at Walou Cave the cortical surfaces of artefacts made of Lanaye flint in both assemblages, indicate that lithic raw materials derive from secondary (i.e. reworked) Pleistocene deposits (Draily 2011d). In fact, all cortical surfaces examined under the stereomicroscope appear to have been affected by secondary transformations (e.g. alterations by mechanical, thermic and chemical processes), in the context of variable geomorphological environments experienced by the raw materials before their collection and use by prehistoric foragers (sensu Turq 2005; Fernandes and Raynal 2006). The major supply sources of suitable raw material are likely to have been from secondary flint deposits, the so-called clays with flint, possibly exposed as colluvial or alluvial gravels in the Vesdre, Geer and Meuse river basins in the vicinity of the site.

Whilst Lanaye flint is the dominant raw material in both Aurignacian and Gravettian occupations of Walou Cave, the presence of four lithic artefacts made of homogeneous high-quality black flint in the Aurignacian assemblage raises the question of longdistance transfer of Western Belgian Campanian flint across an East-West axis. The distance separating Walou Cave from the nearest Western Belgian flint occurrences in the Mons Basin is c. $120 \mathrm{~km}$ as the crow flies.

\section{Lithic Industry}

The Aurignacian and Gravettian lithic assemblages of Walou Cave are relatively small, totaling 301 and 185 lithic artefacts respectively that exceed $10 \mathrm{~mm}$ in length. Retouched tools account for 51 (i.e. 16.9\%) and 40 specimens (i.e. 21.6\%) respectively in the Aurignacian and Gravettian assemblages (Table 1; see 'Lithic Technology' for more details on technology). Almost no Aurignacian and Gravettian artefacts were recovered during the excavations from 1996 to 2004 (Draily 2011a, b, c). Compared to the $40-\mathrm{m}^{2}$ excavated in $1985-1990$, only $3 \mathrm{~m}^{2}$ of the Aurignacian layer has been investigated in later campains. The Gravettian material derives from three spatially distinct 'zones' which could not be correlated stratigraphically; zone 1 is located in the inner cave and zones 2 and 3 are on the cave terrace (Fig. 3; Table 1). In the course of 
the 1985-1990 fieldwork, the Gravettian layer was excavated over $38 \mathrm{~m}^{2}$ in zone 1, 8 $\mathrm{m}^{2}$ in zone 2 and $3 \mathrm{~m}^{2}$ in zone 3 . The excavated surface for the Gravettian layer in 1996-2004 totals $3 \mathrm{~m}^{2}$ in zone 1 only. Zones 1 and 2 are considered to represent largely in situ areas (Draily 2011b, c), with previous radiocarbon dates suggesting repeated occupations through time (Gilot 1993; Pirson et al. 2011b; Supplementary Information A, Table S1). On the contrary, zone 3 represents a reworked area, possibly including artefacts from zones 1 and 2 (Draily 2011b,c).

Systematic dry screening of excavated layers by the quarter square metre was carried out in the course of the 1996 to 2004 excavations, using meshes of $10 \mathrm{~mm}$, $6 \mathrm{~mm}$ and $1 \mathrm{~mm}$ (Draily 2011b). Samples of excavated sediments were regularly bagged to be wet-sieved in the lab. As far as Dewez' earlier fieldwork (1985-1990) is concerned (Dewez 1993, 2008), dry-screening using $10 \mathrm{~mm}$ (perhaps also $6 \mathrm{~mm}$ ) meshes took place, but not in a systematic manner. As a result, it is likely that the small debitage fraction, especially small bladelets from endscraper and burin cores which are so abundant in other Aurignacian sites, is largely underrepresented (Table 1).

The presence of carinated burins in the Aurignacian of Walou Cave is worth mentioning (Kozłowski and Sachse-Kozlowska 1993) (Table 1). In Western Europe, busked and carinated burins are considered to characterise the final stages of the Aurignacian, the so-called evolved Aurignacian in contrast to the Early Aurignacian (Demars and Laurent 1992). The Aurignacian of Walou Cave has been described as 'final Aurignacian with busked burins' (Flas 2015), alongside other Aurignacian sites in Belgium such as Maisières-Canal or Trou du Renard (Dinnis and Flas 2016).

The Gravettian lithic assemblage of Walou Cave is typologically and technologically homogeneous (Klaric 2008). In particular, the presence of Gravette and Microgravette points alongside truncated backed bladelets matches the typological make-up of other cave sites in Belgium that have been attributed to a recent phase of the Gravettian, such as Goyet rock shelter, Engis and Fonds-de-Forêt (Otte 1979; Klaric 2008).

\section{Osseous Industry}

The Aurignacian and Gravettian osseous industry from Walou Cave totals eight and two artefacts respectively (Fig. 4), including five points, four chisels and one awl (Table 2). All ten osseous artefacts from Walou Cave are curated at the Préhistomuseum at Ramioul (Flémalle). The majority of them derive from the Aurignacian layer C6, especially from sub-units C6C and C6D, according to the nomenclature of the 1985-1990 excavations (Table 3). Two osseous projectile points have been described as deriving from Gravettian layer B-5 (Dewez 1989).

Half of the Aurignacian osseous tools can be described as antler projectile points. Generally speaking, Aurignacian projectile points made of antler can be subdivided into two main types: split-based points and simple-based or massive-based points (i.e. points without clear adjusting for hafting), the latter being either lozenge shaped or spindle shaped (Doyon and Katz Knecht 2014; Tejero 2016). Given frequent changes throughout the UP of their base morphology, and hence related hafting systems, osseous projectile points are claimed to be one rare class of osseous artefacts that can 
be positioned in a chrono-cultural sequence (Peyrony 1933; Tartar et al. 2006). Splitbased and massive-based point types tend to follow one another chronologically: splitbased points during the Early Aurignacian and flat lozenge-shaped points during the later Aurignacian periods (Moreau et al. 2015; Peyrony 1933; Tejero 2016). At Walou Cave, three out of four Aurignacian points retain at least a portion of their proximal part. They have in common a lozenge shape and simple base (Fig. 4 (1-3)). Whilst thickness and width remain constant, the points' variable lengths can best be explained in terms of use and maintenance/curation (e.g. Doyon and Katz Knecht 2014).

The two allegedly Gravettian points present different morphologies. The first point corresponds to an incomplete c. $18 \mathrm{~cm}$-long rod with circular cross-section shaped by scraping and polishing (Fig. 4 (9)). The other point presents an oval cross-section (Fig. 4 (10)). It has been scraped and polished and exhibits splintered extremities, attesting to its secondary use as a chisel. Further typological observations on the Aurignacian osseous industry from Walou Cave can be found in Supplementary Information A (Sect. 1).

Table 1 Walou Cave. Tool assemblage composition by cultural layers and spatial zones

\begin{tabular}{|c|c|c|c|c|}
\hline \multirow[t]{2}{*}{ Tool classes } & \multirow[t]{2}{*}{$\begin{array}{l}\text { Aurignacian } \\
(\mathrm{C} 6, \mathrm{CI}-1)\end{array}$} & \multirow{2}{*}{$\begin{array}{l}\text { Gravettian } \\
\text { (B-5: A-D) } \\
\text { Zone } 1\end{array}$} & \multirow{2}{*}{$\begin{array}{l}\text { Gravettian } \\
\text { (B-5X) } \\
\text { Zone } 2 \text { terrasse }\end{array}$} & \multirow{2}{*}{$\begin{array}{l}\text { Gravettian } \\
\text { (B-5) } \\
\text { Zone } 3 \text { terrasse }\end{array}$} \\
\hline & & & & \\
\hline \multicolumn{5}{|l|}{ Endscraper } \\
\hline Simple endscraper on flake & 3 & 0 & 0 & 0 \\
\hline $\begin{array}{l}\text { Endscraper on blade with } \\
\text { lateral retouch }\end{array}$ & 1 & 0 & 0 & 0 \\
\hline Carinated endscraper (core) & 0 & 0 & 0 & 0 \\
\hline \multicolumn{5}{|l|}{ Burin } \\
\hline Carinated (core) & 5 & 0 & 0 & 0 \\
\hline $\begin{array}{l}\text { Multiple (with various } \\
\text { burination types) }\end{array}$ & 6 & 0 & 0 & 0 \\
\hline On truncation (simple or double) & 6 & 0 & 1 & 1 \\
\hline Dihedral (simple or double) & 2 & 0 & 1 & 0 \\
\hline On break & 1 & 2 & 0 & 0 \\
\hline Gravette point & 0 & 1 & 0 & 0 \\
\hline Microgravette point & 0 & 0 & 1 & 0 \\
\hline Backed and truncated bladelet & 0 & 0 & 4 & 0 \\
\hline $\begin{array}{l}\text { Manufacture discard of } \\
\text { backed point }\end{array}$ & 0 & 0 & 2 & 0 \\
\hline Lateral retouch & 15 & 4 & 8 & 0 \\
\hline Truncated blade & 1 & 1 & 1 & 0 \\
\hline Distal retouch (not truncation) & 3 & 0 & 0 & 0 \\
\hline Scraper & 5 & 1 & 1 & 0 \\
\hline Combination tool & 3 & 1 & 0 & 0 \\
\hline Total & 51 & 10 & 19 & 1 \\
\hline
\end{tabular}




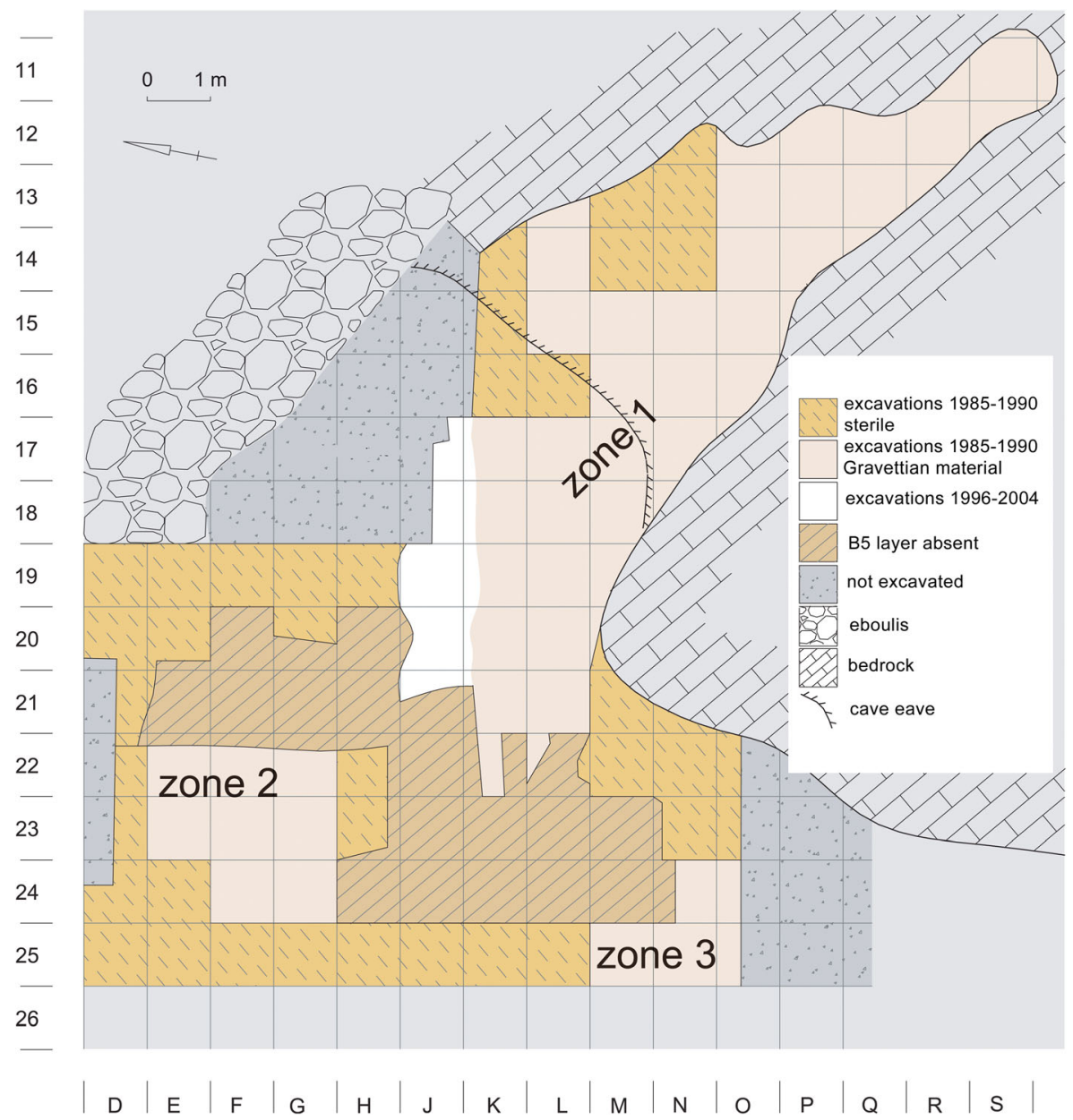

Fig. 3 Walou Cave. Spatial extension of Gravettian layer B-5 and location of the excavation areas (i.e. zones 1,2 , and 3) which yielded Gravettian archaeological material

\section{Materials and Methods}

\section{Technological Organisation}

The interpretation of lithic and osseous assemblage variability is examined through aspects of hunter-gatherer interactions with their natural environment, where technological systems represent pragmatic solutions to the procurement of food resources (e.g. Goutas and Tejero 2016; Kuhn 2004). We draw upon the theoretical framework of 'Technological Organisation' to interpret assemblage variability (see for details Robinson and Sellet 2018). We assume that technological change reflects adaptive responses to environmental change, with the costs and benefits of available alternatives affecting the likelihood of their adoption (Kuhn 2004). In particular, risk is considered to be a major element conditioning forager technology, with technological innovations being most likely under conditions where risk is high (Fitzhugh 2001). Moreover, 
among the multiple factors influencing lithic technological organisation including reduction strategies and tool use, one of the most significant is the availability of suitable raw material (Kuhn 1992). With regard to the UP prior to the LGM, the increased frequency of long-distance raw material transfer during the Gravettian period has occasionally been considered to reflect more effective provisioning and management of lithic resources through increased mobility and acceptance of the higher costs of obtaining high-quality lithic raw materials (Féblot-Augustins 1997, 2009).

We interpret assemblage variability at a regional scale, by investigating possible shifts in the abundance and distribution of mammal species as reflected in the diversity of faunal remains, particularly large game. This information is viewed in relation to patterns of lithic raw material procurement and use with mobility being the point of articulation between these systems (e.g. Blades 1999; Kuhn 1992; Robinson and Sellet 2018).

\section{Radiocarbon Dating}

The improved removal of potential contaminants from ancient samples using chemical pretreatment (Brock et al. 2010), and the extension of calibration curves to 50,000 years ago for radiocarbon dates (Reimer et al. 2013), have led to the increased targeting of

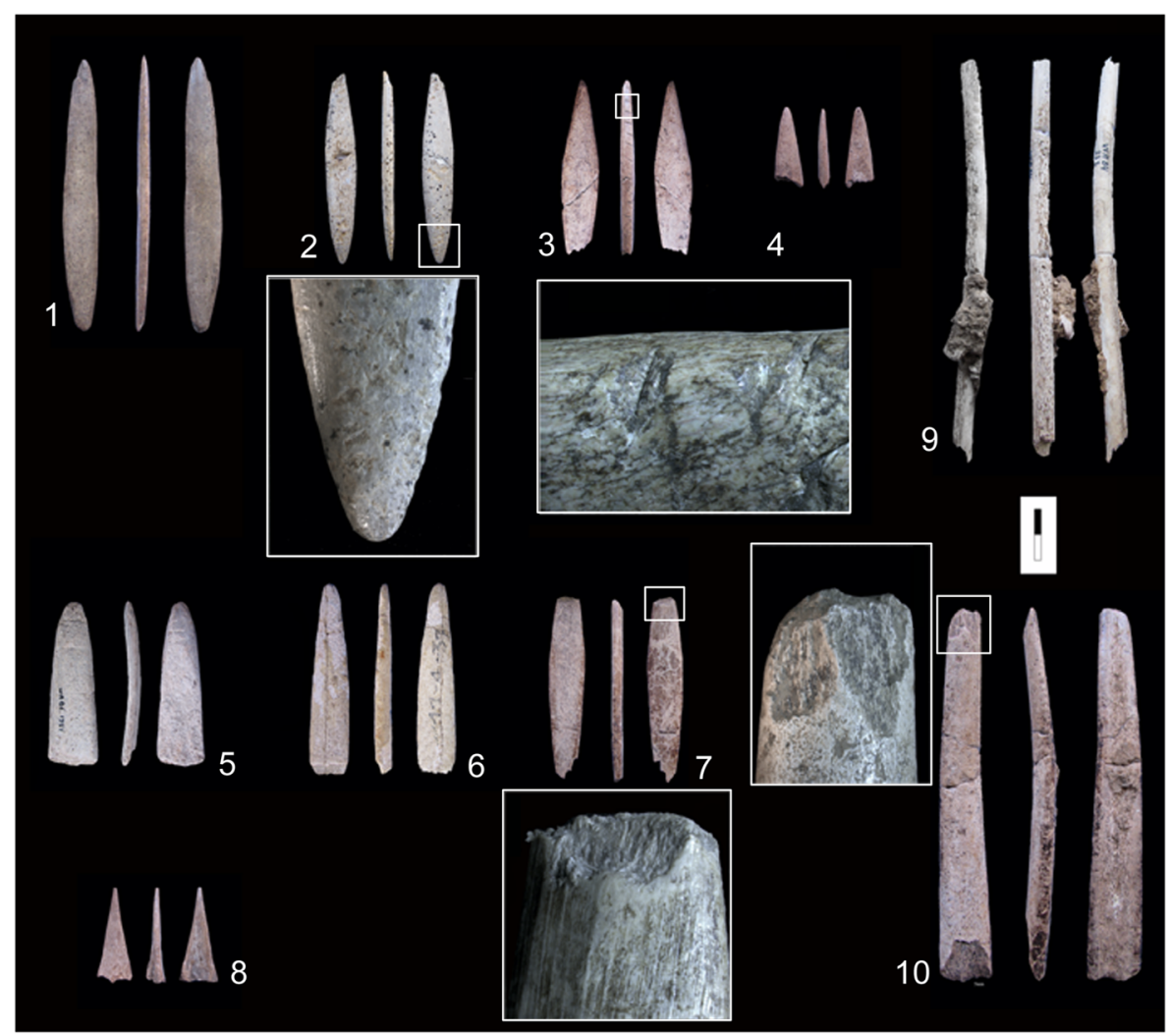

Fig. 4 Osseous artefacts from Aurignacian and Gravettian layers at Walou Cave. 1, WA86/2692; 2 , WA86/2231*; 3, WA86/2693*; 4, WA/4; 5, WA86/1951; 6, WA/3*; 7, WA/5; 8, WA86/2665; 9 , WA84/338*; 10, WA/2*. Scale in centimeters. *Sampled for AMS dating (see also Table 3) 


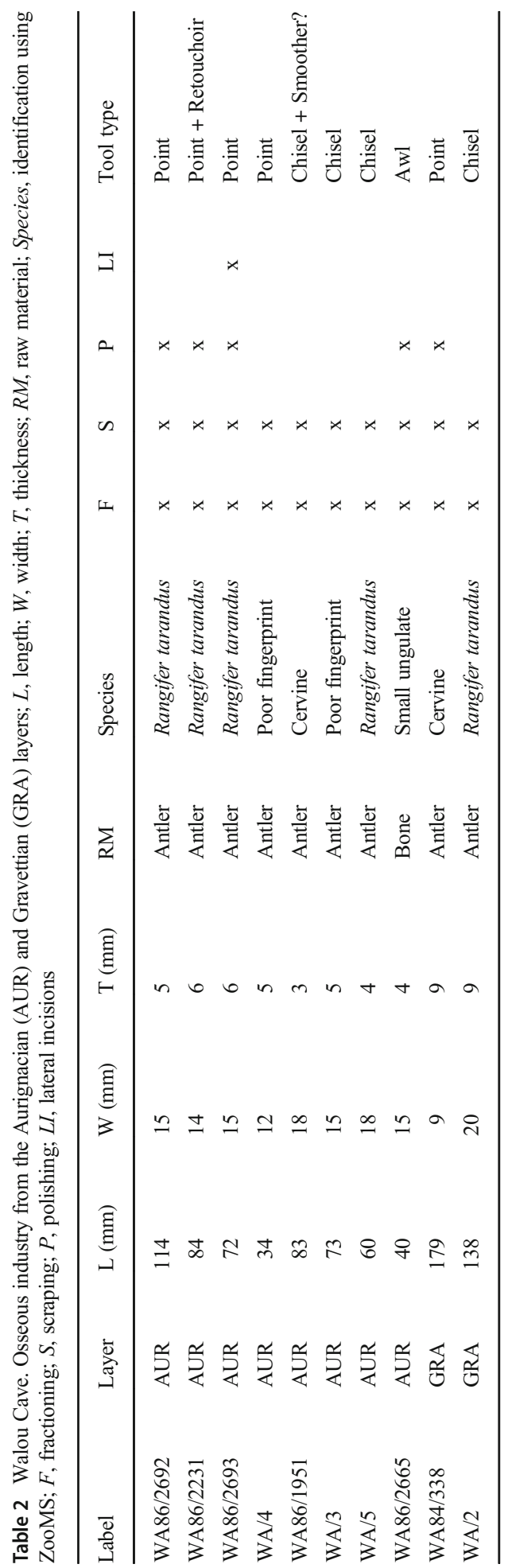


Table 3 Walou Cave. Osseous artefacts selected for AMS dating in this study

\begin{tabular}{llll}
\hline Label & Material & Layer & Cultural attribution \\
\hline WA/2 & Antler artefact & B-5 (?) & Gravettian (?) \\
WA84/338 & Antler artefact & B-5 (?) & Gravettian (?) \\
WA/3 & Antler artefact & $?$ & Aurignacian (?) \\
WA86/2231 & Antler artefact & C6C-C6D & Aurignacian \\
WA86/2693 & Antler artefact & C6C & Aurignacian \\
WA86/2181 & Antler beam fragment & C6 sup. & Aurignacian \\
WA86/2201 & Antler beam fragment & C6C-C6D & Aurignacian \\
WA86/2713 & Antler beam fragment & C6C & Aurignacian \\
\hline
\end{tabular}

osseous artefacts for dating Early Upper Palaeolithic contexts (e.g. Jacobi and Pettitt 2000; Jacobi et al. 2006; Davies and Hedges 2008-2009; Miller et al. 2011; Flas et al. 2012-2013; Moreau et al. 2015). Importantly, the amount of sampled collagen required to construct robust ${ }^{14} \mathrm{C}$-based chronologies is diminishing due to improvements in measurement precision of accelerator mass spectrometry (AMS) techniques (Brock et al. 2010; Bronk Ramsey et al. 2004; Higham 2011).

Directly dating osseous artefacts is particularly appealing given that they are demonstrably anthropogenic in origin and sometimes have diagnostic importance. All the radiocarbon dates available previously for the Aurignacian and Gravettian contexts of Walou Cave were obtained before improvements in chemical pretreatment methods of bone collagen (Gilot 1993; Pirson et al. 2011b). Here, new samples from five antler points and three antler beams from Walou Cave were obtained as powder. The materials selected for AMS dating in this study are listed in Table 3. As far as the antler points are concerned, bone collagen was extracted along existing breaks where possible. If points did not have a breakage surface, then an area was chosen over the fatter part of the point and the surface area removed was minimised as much as possible. A micromotor hand drill fitted with a diamond tipped burr was used to drill into the point at the chosen area. There was no evidence that the bones sampled had been conserved with any medium (e.g. glue). However, the outer surface was first scraped with the burr to a depth of around $2 \mathrm{~mm}$ to remove any surface contamination and then approximately 200-950 mg of bone powder was generated for analysis. This was collected on foil and transferred to a container for collagen extraction.

Radiocarbon dating of collagen was conducted at the Oxford Radiocarbon Accelerator Unit (ORAU). In Oxford, samples received the standard ORAU chemical pretreatment for bone and antler by ultrafiltration, followed by graphitisation and AMS measurement, according to protocols described in detail elsewhere (Brock et al. 2010; Bronk Ramsey et al. 2004; Higham et al. 2006).

\section{Geochemical Sourcing}

Drawing on a recent pilot study that validated the use of geochemical characterisation of Belgian flint to test provenance hypotheses (Moreau et al. 2016), the only four 
artefacts made of black flint from the Aurignacian layer of Walou Cave have been analysed using laser ablation-inductively coupled plasma-mass spectrometry (LAICP-MS), given their potentially exogenous provenance from the Mons Basin in Western Belgium. The analysed artefacts consist of one multiple burin, two possibly retouched fragmented blades and one fragmented bladelet. Given strong macroscopic similarities between Campanian flint (i.e. Obourg, Nouvelles, Spiennes) varieties from the Mons Basin in Western Belgium, and Campanian 'Zeven Wegen' black flint from the Belgian Hesbaye and Dutch southern Limburg regions (De Grooth 2011), we initially investigated whether these flint varieties present distinct geochemical signatures. This step is key to establishing long-distance raw material transfer between Walou Cave and the Mons Basin across c. $120 \mathrm{~km}$. In this study, source locations of the aforementioned flint types were sampled in eastern and western Belgium in primary geological position and geochemically analysed to compare their signature with those of the four Aurignacian black flint artefacts (Supplementary Information B, Tables S1-S5).

In situ high-precision geochemical analyses of major, minor and trace elements were conducted in the Department of Earth Sciences at the University of Cambridge, using an ESI NWR193 excimer laser ablation system interfaced to a Perkin-Elmer NexION 350D ICP-MS, according to the protocol described in Supplementary Information A, Sect. 2.

The multivariate LA-ICP-MS data derived from our geochemical analyses are treated as compositional data (CODA). Given that CODA analysis is concerned with element ratios (i.e. ratios between values), and not with absolute measured values (Aitchison 1986), trace element data are first transformed from their representation in the simplex to the real Euclidean space where statistical methods like discriminant analysis (DA) are capable of revealing patterned compositional variation (Filzmoser et al. 2012). We applied DA to the data set by using the statistical software environment $R$ (R Core Team 2017). We use the isometric log-ratio (ilr) transformation given its good geometric properties and avoidance of singularity issues later on in DA. DA has been used to quantify the probability of group integrity, and to assess the likelihood of a particular artefact belonging to a prespecified group. Where overlap of two or more geological groups occurred, DA was used to find the group that the artefact was most similar to statistically.

For the statistical analysis, all elements without missing values are used. Values below the detection limit are set to $2 / 3$ of the smallest measured value (MartinFernandez et al. 2011). In total, 29 variables (i.e. major, minor and trace elements) were measured effectively and used for statistical analysis (Supplementary Information A, Sect. 2; Supplementary Information B).

All observations (i.e. measurements) for the four control groups Obourg (OB), Nouvelles (NO), Spiennes (SP) and Zeven Wegen (ZW) are used as training data for DA (Johnson and Wichern 2007), since their lithostratigraphic and geographic provenance is known (Supplementary Information A, Table S2). We use linear DA (Fisher LDA) instead of quadratic DA in order to avoid instability or even singularity in the results. Discriminant rules are built with the training data, and they are employed to classify the measured artefacts (i.e. test data) with unknown group membership to one of the three prespecified chemical groups. 


\section{Archaeozoological Analysis}

With the exception of eight determined faunal material from the most recent excavations (De Wilde 2011), the large majority of faunal material analysed and published to date for the Aurignacian of Walou Cave derive from Dewez' excavation campaign of 1985/1986 (Simonet 1993, p. 61) (Supplementary Information A, Table S3). These appear to represent only $24 \%$ of the total Aurignacian faunal assemblage excavated between 1985 and 1990 (i.e. 180 from 744 inventoried remains). The faunal remains from the Gravettian layers (i.e. B-5: A-D; B-5X) were previously unpublished (Supplementary Information A, Tables S4-S7). Thus, the present account is the first comparative analysis of the faunal composition and possible subsistence strategies between both Aurignacian and Gravettian periods. Although the fauna from Gravettian layers from inside (B-5: A-D) and outside (B-5X) the cave are likely part of the same deposit, we restrict our discussion here to those from B-5 (A-D). B-5X is too small for worthwhile analysis from a statistical point of view.

We have measured faunal diversity (i.e. distribution of abundance amongst species) using both NTAXA (number of identified taxa or species) values and Simpson's Index (Magurran 1988; Grayson 1984; Boyle 1990) to ensure inter-assemblage comparison at the site level and broad comparability with existing results of faunal assemblages at the broader European scale. Whilst similarities in NTAXA in archaeological faunal assemblages do not necessarily reflect similarities in average diet breadth (Grayson and Delpech 1998), the use of Simpson's Index is particularly useful to identify significant differences in NTAXA values, which in turn might well be meaningful in terms of human adaptation.

Hypotheses on resource intensification and dietary diversification between Aurignacian and Gravettian assemblages have not been taken into consideration and will not be discussed here, since anthropogenic modifications have been investigated for part of the Aurignacian fauna only (Simonet 1993, pp. 56-57). A detailed taphonomic analysis of both Aurignacian and Gravettian faunal assemblages remains to be undertaken.

\section{Zooarchaeology by Mass Spectrometry}

Given the absence of morphologically diagnostic criteria for species identification, nine out of ten osseous artefacts from Walou Cave were analysed by collagen fingerprinting technique for species identification by Zooarchaeology by Mass Spectrometry (ZooMS) in order to identify the faunal taxa from which they were manufactured. For practical reasons, four specimens were sampled using several approaches: a nondestructive approach which involved using polishing film was tested, in addition to a more commonly used minimally destructive approach tested on the same samples following a modified form of the method proposed by Buckley et al. (2016) (see, for more details, Supplementary Information A, Sect. 3).

Taxonomic identification by collagen peptide mass fingerprinting is most commonly based on only a few selected peptide markers (Buckley et al. 2014), although machine learning approaches have also recently been employed ( $\mathrm{Gu}$ and Buckley 2018). However, the absence of a specific peptide marker in any given spectra has implications for the taxonomic level at which an identification will be made. 


\section{Results}

\section{New Radiocarbon Dates}

For Walou Cave, four samples (including three osseous points) contained enough collagen to allow dating with confidence (Table 4). The reliability of the obtained results is indicated by the elemental and isotopic values of the dated samples. The Carbon to Nitrogen $(\mathrm{C} / \mathrm{N})$ atomic ratio ranges from 3.17 to 3.25 and is thus within normal parameters (Bronk Ramsey et al. 2004; Higham 2011). Collagen yields were high and the $\% \mathrm{C}$ values are consistent and identical with normal expected amounts from well-preserved collagen at the ORAU.

We did not retain any of the four radiocarbon dates previously available for the Aurignacian of CI-1 (Table S1) (Gilot 1993). Two dates can be rejected given acknowledged problems with dating humic sediment fractions (Pirson et al. 2011b). From the remaining two radiocarbon dates of 29,800 \pm 760 and 29,470 \pm 640 uncal BP for CI-1, one was obtained on multiple bone fragments, the other on several charcoal samples described as deriving from hearth waste (Dewez 1993). Based on these dates, it has been suggested that CI-1 at Walou Cave correlates with the archaeologically sterile humiferous palaeosol MD at Maisières-Canal (Champ de Fouilles) (Pirson et al. 2011 b, 2012), dated to $30,780 \pm 400$ uncal BP and correlated with the Denekamp I Interstadial defined in The Netherlands (Haesaerts 2004). However, the reliability of the aforementioned radiocarbon dates for CI-1 at Walou Cave has been recently called into question (Flas 2015; Dinnis and Flas 2016) given the risks inherent in obtaining radiocarbon dates based on 'multiple-entity' samples of charcoal or bone (Pettitt et al. 2003). There are several other indications that the previous radiocarbon dates available for CI-1 can be regarded as underestimates. Firstly, on the grounds of similarities in the typological make-up of the Aurignacian lithic assemblages from Walou Cave and Maisières-Canal (Berge Nord-Est) (Flas 2015). Additionally, given the stratigraphic position of the Aurignacian in the Maisières sequence, deriving from humiferous horizon NBD below interstadial Unit MD, hence must be older than 30,780 BP (Flas 2015; Dinnis and Flas 2016). Our new dates validate this interpretation (Table 4).

We calibrated the new radiocarbon dates for the Aurignacian of Walou Cave, using the IntCal13 calibration curve and OxCal 4.3.2 (Reimer et al. 2013) at 95.4\% probability (Figs. 5 and 6). By comparing the calibrated three new radiocarbon dates obtained by directly dating Aurignacian osseous points against the Greenland NGRIP ice core (Andersen et al. 2006), the two earlier dates $(32,400 \pm 500$ and $32,700 \pm 450$ uncal BP) suggest the correlation of Aurignacian layer CI-1 at Walou Cave with the end of Greenland Interstadial GI-8 (Fig. 5). These dates are consistent with the chronostratigraphic position of other Belgian Aurignacian occupations bearing the same technologies, particularly Maisières-Canal (Berge Nord-Est) where the humiferous horizon NBD which yielded Aurignacian material has been correlated with the Huneborg II Interstadial in the sequence from The Netherlands, estimated to date between 32 and $33.3 \mathrm{ka}$ uncal BP (Haesaerts 2004). Whilst partially overlapping, the slightly younger date of $31,350 \pm 400$ uncal BP for CI-1 might indicate an additional later occupation of Walou Cave in correlation with GI-7 (Fig. 5). Either way, the palaeoenvironmental proxies for CI-1 indicate the existence of a climatic amelioration of interstadial character in connection with the Aurignacian occupation, based on 
Table 4 Details of the samples selected for radiocarbon dating in this study. CRA is the conventional radiocarbon age, expressed in uncalibrated radiocarbon years BP (Before Present-AD 1950) using the Libby $14 \mathrm{C}$ halflife of 5568 years. Gelatin yield represents the weight of ultrafiltrated gelatin in milligrams (Higham 2011). \% Yld is the percent yield of extracted collagen as a function of the starting weight of the bone analysed. $\% \mathrm{C}$ is the carbon present in the combusted gelatin. $\mathrm{C} / \mathrm{N}$ is the atomic ratio of carbon to nitrogen and is acceptable if it ranges between 2.9 and 3.5 (Higham 2011). One sample has been given an OxA-X rather than an OxA-prefix, which reflects the added uncertainty since the graphite of the sample was $40 \%$ of the expected current, hence the error term is higher than it ought to be

\begin{tabular}{lllllllllllll}
\hline ID & Material & $\begin{array}{l}\text { OxA } / \\
\text { OxA-X }\end{array}$ & CRA & $\begin{array}{l}\text { Used } \\
(\mathrm{mg})\end{array}$ & $\begin{array}{l}\text { Yield } \\
(\mathrm{mg})\end{array}$ & $\begin{array}{c}\% \text { yield } \\
\% \mathrm{C}\end{array}$ & $\begin{array}{l}\delta 13 \mathrm{C} \\
(\%)\end{array}$ & $\begin{array}{l}\delta 15 \mathrm{~N} \\
(\% \circ)\end{array}$ & $\mathrm{C} / \mathrm{N}$ \\
\hline WA86/2231 & Antler & 35,208 & 32,400 & 500 & 220 & 5.97 & 2.7 & 44 & -18.19 & 1.73 & 3.25 \\
WA86/2693 & Antler & 35,209 & 31,350 & 400 & 260 & 5.32 & 2 & 44.2 & -19.56 & 2.32 & 3.20 \\
WA86/2201 & Antler & 35,210 & 32,700 & 450 & 530 & 21.49 & 4.1 & 44.3 & -20.04 & 2.41 & 3.20 \\
WA84/338 & Antler & X-2711-15 & 12,640 & 80 & 300 & 5.41 & 1.8 & 42.4 & -19.89 & 1.56 & 3.17 \\
WA86/2181 & Antler & Failed & - & - & - & - & - & - & - & - & - \\
WA/2 & Antler & Failed & - & - & - & - & - & - & - & - & - \\
WA/3 & Antler & Failed & - & - & - & - & - & - & - & - & - \\
WA86/2713 & Antler & Failed & - & - & - & - & - & - & - & - & - \\
\hline
\end{tabular}

palynology, magnetic susceptibility, microfauna and the presence of small speleothems. This is in agreement with the climatic signals recorded by pedological and sedimentary processes (see above 'Palaeoenvironmental Framework'). It cannot be ruled out that the humiferous horizon CI-1 conflates both interstadial episodes GI-8 and GI-7.

As far as the two osseous points allegedly of Gravettian origin (Dewez 1989) are concerned, one date failed due to poor collagen preservation, and the other yielded an unexpectedly young radiometric determination of $12,640 \pm 80$ uncal BP (Table 4). Whilst this sample had a low target current for the graphite in the accelerator (i.e. $40 \%$ of the expected current), ORAU does not usually see substantial age shifts with lower currents, at least not of the order required to shift the age from the Gravettian to $12 \mathrm{ka}$ BP like this (ORAU, personal communication). However, it is worth noting the very low collagen content of the sample (Table 4). The measurement could not be repeated because there is no remaining sample. This date exemplifies the poor understanding of cave site formation processes which has undergone major improvements since Dewez' excavations (see, for details, Pirson 2011; Pirson et al. 2011a), rather than calling into question the integrity of Dewez' lithostratigraphic and chonostratigraphic frameworks (Collcutt 1993). This new date might indicate intermixture with younger, possibly Magdalenian material from layer B-4, directly on top of Gravettian layer B-5. Unfortunately, it is unclear from which part of the cave the said osseous point (Fig. 4 (9)), which Dewez (1989) has attributed to the Gravettian, derives from. The point is an antler rod obtained by the 'double longitudinal grooving' technique, which is unknown prior to the Gravettian (Goutas 2009; Averbouh et al. 2016). However, on technotypological grounds an attribution to the Magdalenian is equally conceivable.

We calibrated the available dates for the Gravettian of Walou Cave (Fig. 6). From the four radiocarbon dates previously published (Gilot 1993, 1997; Pirson et al. 2011b), three can be disregarded given the risks of obtaining dates from 'multiple-entity' 
samples of bone (Pettitt et al. 2003). We favour the date of 22,800 \pm 400 uncal BP as representative for the Gravettian occupation of zone 1, since this date has been obtained from a piece of worked antler which derives from the inner part of the cave (Zone 1) (Gilot 1993).

\section{Lithic Technology}

The Aurignacian-Gravettian lithic sequence from Walou Cave is marked by continuity and changes. The strategy for managing supplies of blade and bladelet tools in the Aurignacian of Walou Cave is characterised by the conceptual dissociation of blade and bladelet productions - a feature typical of the Aurignacian in Western and Central Europe (e.g. Bodu et al. 2013; Bon et al. 2005; Brou and Le Brun-Ricalens 2005; Mevel 2013; Moreau et al. 2015; Nigst 2012). Whilst carinated burins have been included here in the category of modified tools for the purpose of inter-assemblage comparisons, they are now commonly understood as part of a specific system of bladelet production allowing for a high degree of control over the morphology of the desired blank (e.g. Brou and Le Brun-Ricalens 2005). At Walou Cave, a series of eight so-called burin spall bladelets of type Thèmes (i.e. 'tablette lamellaire de type Thèmes', sensu Brou and Le Brun-Ricalens 2005) can be assigned to the aforementioned burin core technology (Table 5).

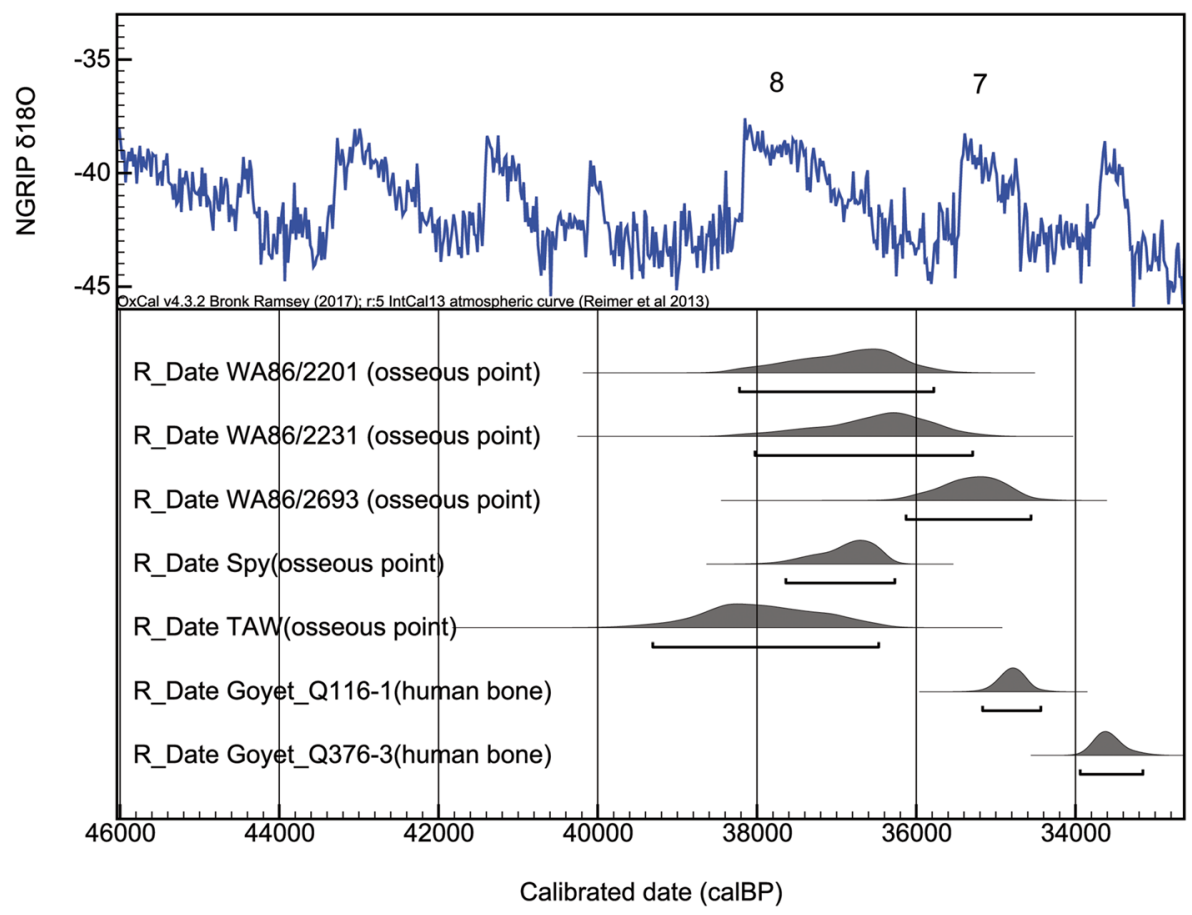

Fig. 5 Walou Cave (WA). Calibrated dates BP for the Aurignacian occupation (using Oxcal calibration). See text for details. The NGRIP data is after Andersen et al. (2006), and the numbers 8 and 7 on top of the NGRIP ice-core record curve refer to Greenland Interstadials (GI) 8 and 7 (Rasmussen et al. 2014). Calibrated dates for Spy, Trou Al'Wesse (TAW) and Goyet Cave (dated samples: Q116-1 and Q-376-3) derive from radiocarbon dates published elsewhere (Miller et al. 2011; Posth et al. 2016; Semal et al. 2013) 


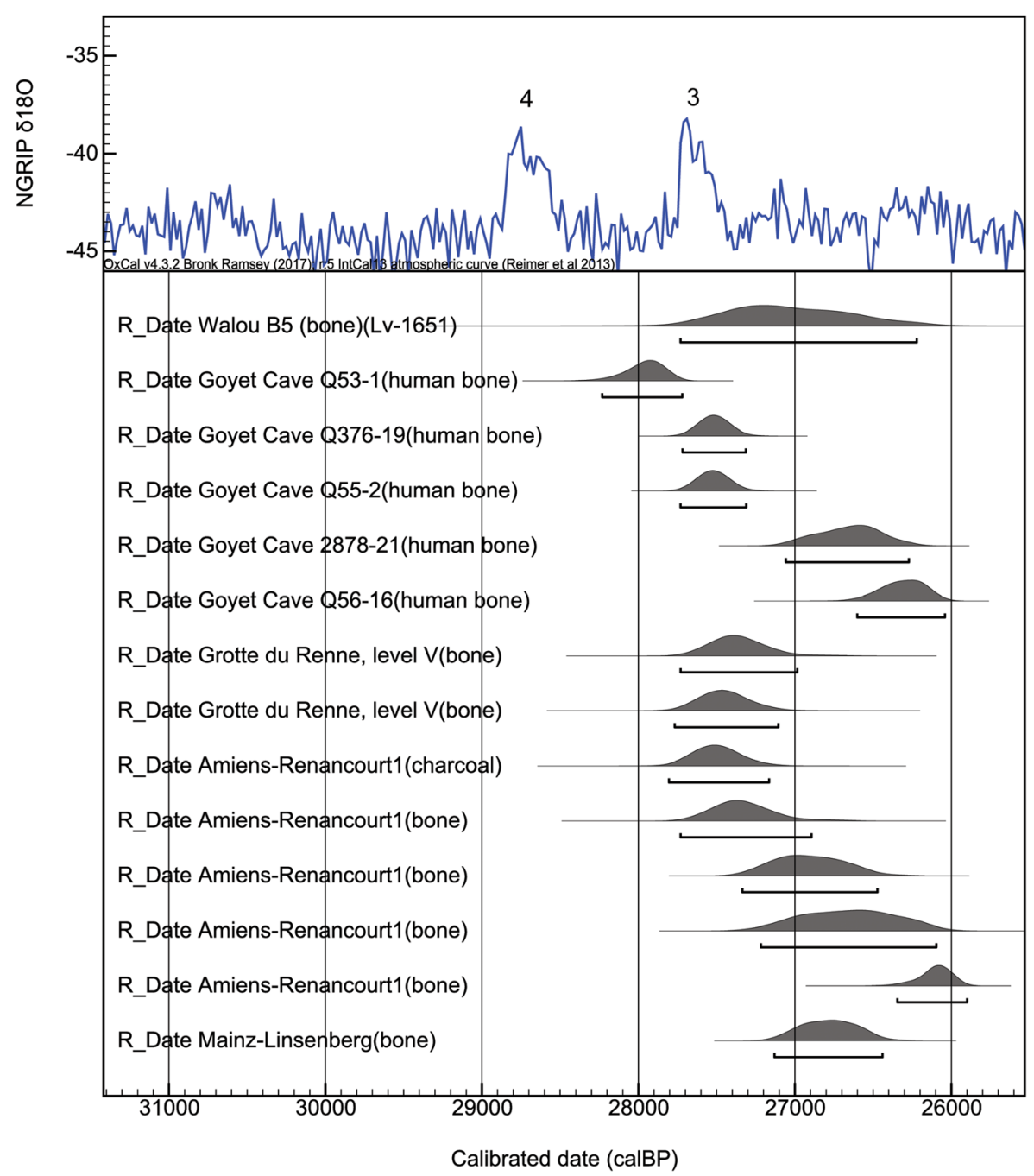

Fig. 6 Walou Cave. Calibrated dates BP for the Gravettian occupation (using Oxcal calibration). See text for details. The NGRIP data is after Andersen et al. (2006), and the numbers 4 and 3 on top of the NGRIP ice-core record curve refer to Greenland Interstadials (GI) 4 and 3 (Rasmussen et al. 2014). Calibrated dates for Walou Cave, Goyet Cave (dated samples: Q53-1; Q376-19; Q55-2; 2878-21; Q56-16), Grotte du Renne, level V (Arcy-sur-Cure), Amiens-Renancourt 1, all derive from radiocarbon dates published elsewhere (Gilot 1993; Higham et al. 2010; Terberger 2013; Posth et al. 2016; Paris et al. 2017)

On the contrary, the Gravettian at Walou Cave features continuous blade and bladelet production from volumetric cores. Gravettian blank production was typically aimed at obtaining regular, mainly small-sized blades with a straight profile, which were primarily intended for the manufacture of backed implements (Klaric 2008). The most striking features of changes to core technology and laminar blank production compared to the Aurignacian are apparent in scar patterns in relation to bipolar debitage. In addition, the use of the soft stone hammer (sensu Pelegrin 2000), in 
relation to the production of straight laminar blanks, represents an original technological feature of the Gravettian lithic industry at Walou Cave (Klaric 2008).

In both Aurignacian and Gravettian lithic industries, core reduction was mainly unidirectional, as indicated by a large majority of unidirectional laminar scar removals on both Aurignacian and Gravettian laminar blanks (with sample sizes of $N=66$ and $N$ $=115$ ). However, a gradual increase in bidirectional scar removals is noticeable in the Gravettian. Together with the use of the soft stone hammer, the presence of bidirectional scar removals on laminar blanks (i.e. $11 \%, N=13$ ) likely reflects alternating debitage from opposite striking platforms to correct the distal convexities of the removal surface. Core reduction from two opposite platforms is generally seen as a corollary feature of the maintenance of a straight and transversally convex debitage surface in relation to the production of straight laminar blanks, as documented in various other Gravettian contexts (e.g. Klaric 2003; Pelegrin 2011; Touzé 2018).

At Walou Cave, technological changes between the Aurignacian and Gravettian with regard to core maintenance and percussion techniques are further evident in the general dimensions of blades and bladelets from volumetric cores produced at the site over time. Significantly different width-thickness ratios ( $t$ test width-thickness, $t$ test: $p$ $=0.02$ ) testify to gradually decreasing medial width and thickness of laminar blanks from the Aurignacian to the Gravettian (Fig. 7). No significant increase in elongation

Table 5 Walou Cave. Lithic assemblage structure, including both retouched and unretouched blanks, shatter, and volumetric cores, deriving from the 1985 to 1990 and 1996 to 2004 excavation programmes. Bladelets are classified as small blades with a width of $<12 \mathrm{~mm}$ obtained from volumetric cores. Approximately 40 lithic artefacts labelled as deriving from layer B of Dewez' excavations, without any further specification, have not been included in this study, even though we cannot exclude that they derive from Gravettian layer B-5

\begin{tabular}{|c|c|c|c|c|c|c|c|c|c|}
\hline \multirow[t]{3}{*}{$\begin{array}{l}\text { Technological } \\
\text { categories }\end{array}$} & \multirow[t]{3}{*}{ Aurignacian (C6, CI-1) } & \multirow[b]{3}{*}{$N$} & \multirow[b]{3}{*}{$\%$} & \multirow{2}{*}{\multicolumn{2}{|c|}{$\begin{array}{l}\text { Gravettian } \\
\text { (B-5: A-D) } \\
\text { Zone } 1\end{array}$}} & \multirow{2}{*}{\multicolumn{2}{|c|}{$\begin{array}{l}\text { Gravettian } \\
(\mathrm{B}-5 \mathrm{X}) \\
\text { Zone } 2\end{array}$}} & \multirow{2}{*}{\multicolumn{2}{|c|}{$\begin{array}{l}\text { Gravettian } \\
\text { (B-5) } \\
\text { Zone } 3\end{array}$}} \\
\hline & & & & & & & & & \\
\hline & & & & $N$ & $\%$ & $N$ & $\%$ & $N$ & $\%$ \\
\hline \multirow[t]{4}{*}{ Blade } & Simple & 46 & 15.28 & 9 & 15.52 & 49 & 42.61 & 1 & 8.33 \\
\hline & Primary and neo-crested blade & 2 & 0.66 & 0 & 0 & 4 & 3.48 & 0 & 0 \\
\hline & Secondary crested blade & 6 & 1.99 & 2 & 3.45 & 9 & 7.83 & 0 & 0 \\
\hline & Maintenance/trimming blade & 6 & 1.99 & 2 & 3.45 & 5 & 4.35 & 3 & 25.00 \\
\hline Bladelet & Simple & 13 & 4.32 & 9 & 15.52 & 32 & 27.83 & 1 & 8.33 \\
\hline \multirow[t]{3}{*}{ Flake } & Trimming flake & 152 & 50.50 & 31 & 53.45 & 11 & 9.57 & 6 & 50.00 \\
\hline & Cortical flake (cortex $>60 \%)$ & 4 & 1.33 & 0 & 0 & 1 & 0.87 & 0 & 0 \\
\hline & $\begin{array}{l}\text { Core tablet or core platform } \\
\text { preparation flake }\end{array}$ & 3 & 1.00 & 1 & 1.72 & 1 & 0.87 & 1 & 8.33 \\
\hline \multirow[t]{2}{*}{ Burin spall } & Simple & 44 & 14.62 & 2 & 3.45 & 3 & 2.61 & 0 & 0 \\
\hline & $\begin{array}{l}\text { Tablette lamellaire de } \\
\text { type Thèmes }\end{array}$ & 8 & 2.66 & 0 & 0 & 0 & 0 & 0 & 0 \\
\hline Shatter & & 12 & 3.99 & 1 & 1.72 & 0 & 0 & 0 & 0 \\
\hline Volumetric core & & 5 & 1.66 & 1 & 1.72 & 0 & 0 & 0 & 0 \\
\hline Total & & 301 & 100 & 58 & 100 & 115 & 100 & 12 & 100 \\
\hline
\end{tabular}


towards the Gravettian as expressed by the length-width ratio could be demonstrated ( $t$ test length-width, $p=0.24$ ). We suspect this might be the result of limited sample size of complete Aurignacian laminar blanks. In any case, these changes suggest that the production of backed points which accompanied the Gravettian was part of a larger set of technological changes to blade production, the main features of which were the decreasing width and thickness and increasingly straight laminar blanks in relation to the use of soft stone hammer.

The limited number of artefacts in both Aurignacian and Gravettian assemblages that could be refitted might indicate a spatial segmentation of the reduction sequences of suitable raw materials, separating between initial procurement at nearby flint sources and their processing on-site. In fact, the numerical importance of retouched tools (see 'Lithic Industry') compared to the low representation of cortical artefacts and volumetric cores suggests that lithic raw materials were brought to the site primarily as retouched tools alongside prepared cores for the on-site production of small blades (Table 5). However, bearing in mind that on the cave terrace both Aurignacian (CI-1) and Gravettian (B-5) layers have been truncated by variably pronounced erosional phases (Pirson 2011), the assemblages recovered during excavations might not provide a full picture of the activities carried out at the site.

\section{Osseous Technology}

The technological approach adopted here is based on the relevant literature (e.g. Borgia et al. 2016; Tejero et al. 2012; Goutas and Tejero 2016). We analysed manufacturing and use evidence by adopting a combined macroscopic and microscopic approach which involved the use of a stereomicroscope with a magnification up to $\times 70$. Surface preservation of the osseous industry from Walou Cave is good. None of the osseous artefacts examined in this study exhibits carnivore scavenging in terms of gnawing or chewing marks. With the exception of the fragment of an awl made of a metatarsal of a small ungulate, all modified osseous artefacts of Walou Cave are made of antler. Although points made of mammoth ivory are relatively abundant in the Aurignacian of Belgium and the German Rhineland (Otte 1979; Hahn 1995), only three pieces of worked ivory were found at Walou Cave (Dewez 1993, p. 63).

It has been claimed that bone tools were largely intended for domestic or daily activities, whilst antler objects were part of the hunting equipment of Aurignacian groups given the unique morpho-structural properties of antler which make it the best
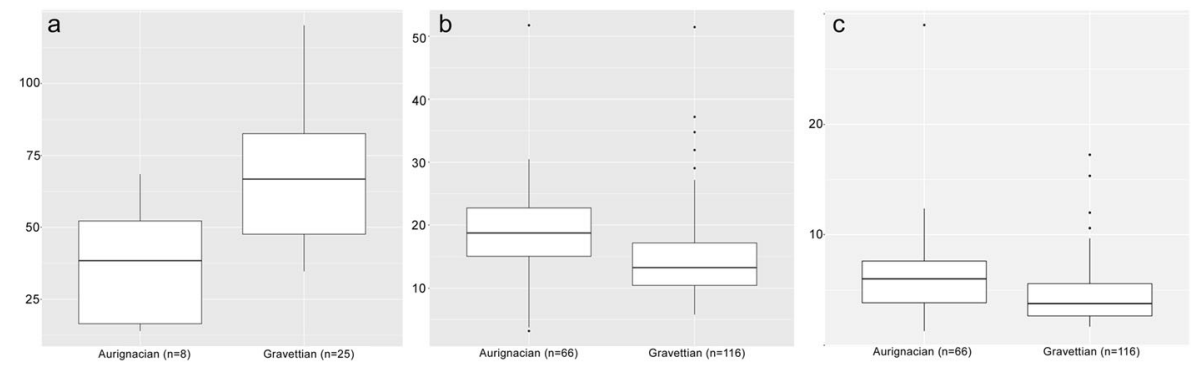

Fig. 7 Aurignacian and Gravettian laminar blanks from Walou Cave: a medial length of complete laminar blanks only; b medial width of all laminar blanks; c medial thickness of all laminar blanks 
osseous material for the manufacture of projectile points (Tartar et al. 2006; Tejero 2014, 2016). This holds for the Aurignacian of Walou Cave, where the exploitation of antler was mainly focused on manufacturing osseous points. A small number of 'technical pieces' (i.e. processing waste such as raw material blocks, blanks, preforms and waste) attests to on-site antler exploitation and allows partial reconstruction of the chaîne opératoire for antler points (Fig. 8). Surprisingly, the two Aurignacian antler bases have both been identified as red deer (Fig. 8 (6-7)), indicating that the antler remains exploited for technical purposes in the Aurignacian correspond at least partly to by-products of Cervus elaphus, which numerically follows reindeer in the faunal composition. From the two antler bases, one derives from a shed antler (Fig. 8 (6)) and the other bears striking marks all around as a result of the process of cutting it off from the animal's skull (Fig. 8 (7)) (Goutas and Tejero, oral communication).

At Walou Cave, the first step in the manufacturing process of Aurignacian points consists of removing the tines of the antler through strokes, followed by transversal cross-sectioning of the beam in order to obtain several cylindrical blocks (Fig. 8 (1-2)). The latter were destined to be used for further longitudinal splitting into elongated blanks, probably through longitudinal diffuse direct percussion likely with the use of a wedge. The tines themselves might have been used to manufacture tools or serve as hammers (Fig. 8 (4)). However, in most cases surface preservation does not allow for the secure identification of anthropogenic marks. Of the two allegedly Gravettian points, one is a fragmented antler rod (Fig. 4 (9)), obtained by the 'double longitudinal grooving' technique. This technique allows for a high degree of control over the morphology of the desired rod in all three dimensions and is particularly useful for producing long, thin and perfectly straight rods (Goutas 2009; Averbouh et al. 2016).

\section{Flint Sourcing}

Our results demonstrate for the first time geochemically the existence of long-distance transport of flint across Belgium during the UP. The LDA method used to analyse the geochemical data is based on an estimation of the common covariance (Todorov and Filzmoser 2009). Data were transformed using an isometric log-ratio approach with estimates for group centres based on training data (i.e. geological samples). The LDA classification model based on the training data can be applied to the same test data (i.e. archaeological samples), which results in a misclassification error of $15 \%$, the so-called 'apparent error rate'. In the corresponding plot of the first two LDA scores (Fig. 9a) the true group labels are shown in different colours, and the predicted group membership as symbols.

We decided to validate the matching of artefacts to sources or geological formations based on the statistical interpretation of the results. Confidence in the assignment of any particular artefact to a geological group depends on the membership of the group and the degree of distinction of boundaries between compositional groups (Filzmoser et al. 2012). In this study, the problem of misassignment has been partially circumvented by identifying the most likely source of each geological specimen independent of its known group affiliation by means of LDA. The classification rules of the LDA method derived from the training data (i.e. geological samples) have then been applied to the test data (i.e. archaeological samples). Four ablation values and one median value for each archaeological sample were assigned to the most probable geological group using 


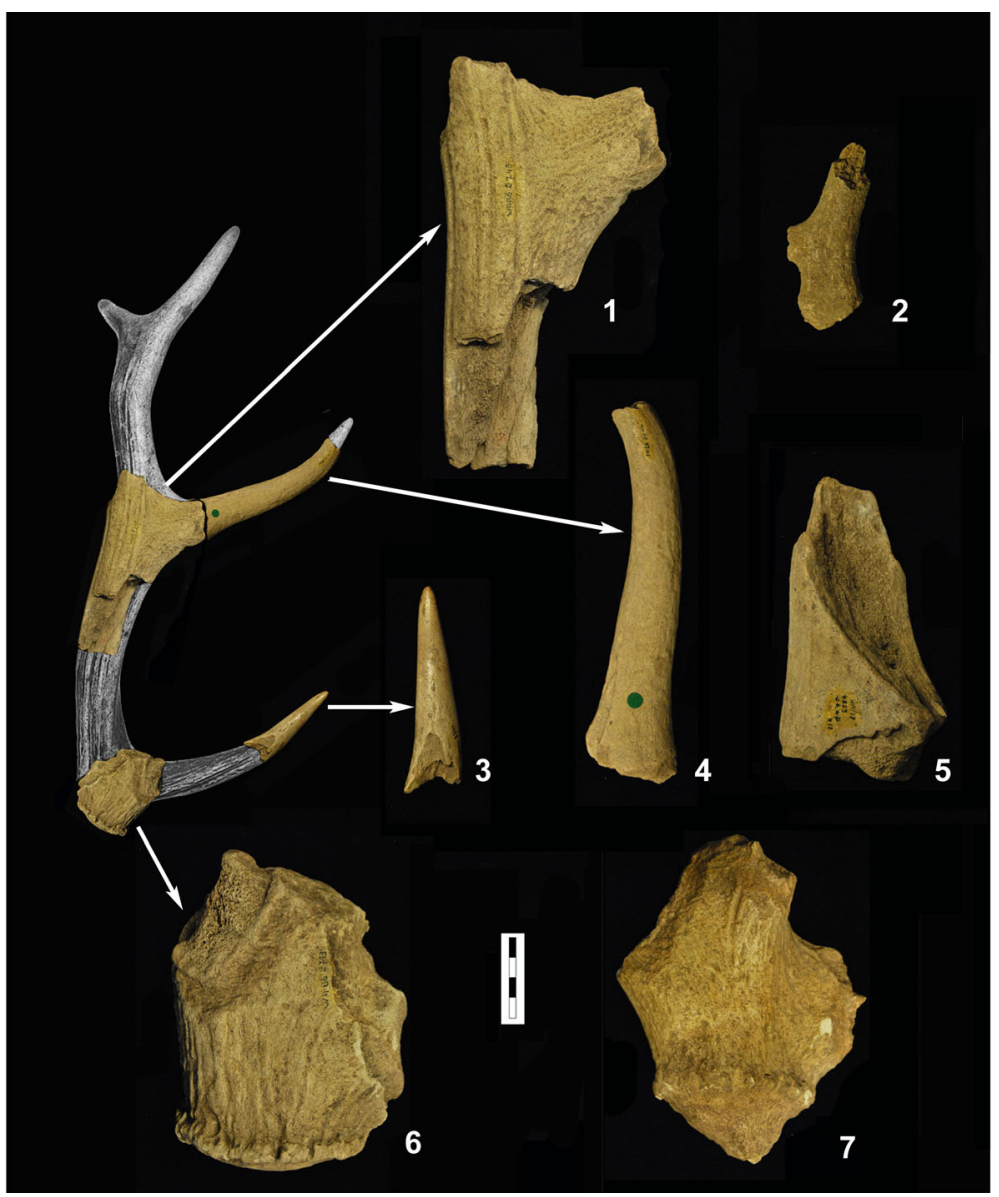

Fig. 8 Walou Cave. Antler remains, likely to represent technical by-products of the Aurignacian osseous industry. Sampled for AMS radiocarbon dating: 2, WA86/2181; 4, WA86/2201; 6, WA86/2713

the LDA method (Supplementary Information A, Table S2, Sect. 2). Results show a fairly limited misclassification rate for the test data based on statistical predictions. All four archaeological samples are within the range of compositional variability of the Spiennes (SP), Nouvelles (NO) and Obourg (OB) groups and are likely to derive from these sources (Fig. 9b). None of the samples can be reliably assigned to the Zeven Wegen (ZW) geological source as only a single ablation from WA-1 is predicted to belong to this source. We are well aware of the limited sample size for ZW geological material, which consists of only six measurements from one single flake. The geochemical variability of ZW flint will have to be refined through further analyses and will require enlarging of the sample database for the Belgian Hesbaye and Dutch Limburg regions. Two of the four archaeological samples (WA-1, WA-2) are predicted to belong to either the SP or NO geological sources whilst the other two archaeological samples (WA-3, WA-4) can be more definitively assigned to the OB geological source. 


\section{Faunal Composition}

The taphonomic role of human foragers versus cave bear (Ursus spelaeus) and hyaena (Crocuta spelaea) in the taxonomic composition of the Aurignacian and Gravettian faunas of Walou Cave (Supplementary Information A, Tables S3-S5) remains to be properly investigated. At least part of the Aurignacian and Gravettian faunas might be the result of carnivore activity (De Wilde 2011). In fact, Walou Cave was repeatedly used by cave bear for hibernation. It thus comes as no surprise that in both Aurignacian and Gravettian assemblages, the bulk of the fauna attributable to the order 'Carnivora' has been identified as Ursus spelaeus and probably relates to the use of the cave as a winter den. There is a limited number of lithic artefacts, comprising 250 lithic debitage by-products and 51 modified tools in Aurignacian layer CI-1 and 155 lithic debitage by-products and 30 modified tools in Gravettian layer B-5. Based on this, and the additional fact that both Aurignacian and Gravettian layers yielded only very limited traces of fire through the presence of burnt bone (Dewez 1993; Draily 2011a), it is likely that the tenancy of Walou Cave must have been firmly in the hands of hibernating bears throughout the sequence whereas human occupation was at best episodic. In contrast, hyaena remains are abundant in the lower (i.e. Middle Palaeolithic) archaeological layers (De Wilde 2011), whereas hyaena is only poorly represented in both Aurignacian and Gravettian assemblages, suggesting limited differences in terms of the taphonomic role played by large carnivores in the Aurignacian and Gravettian assemblages at Walou Cave.
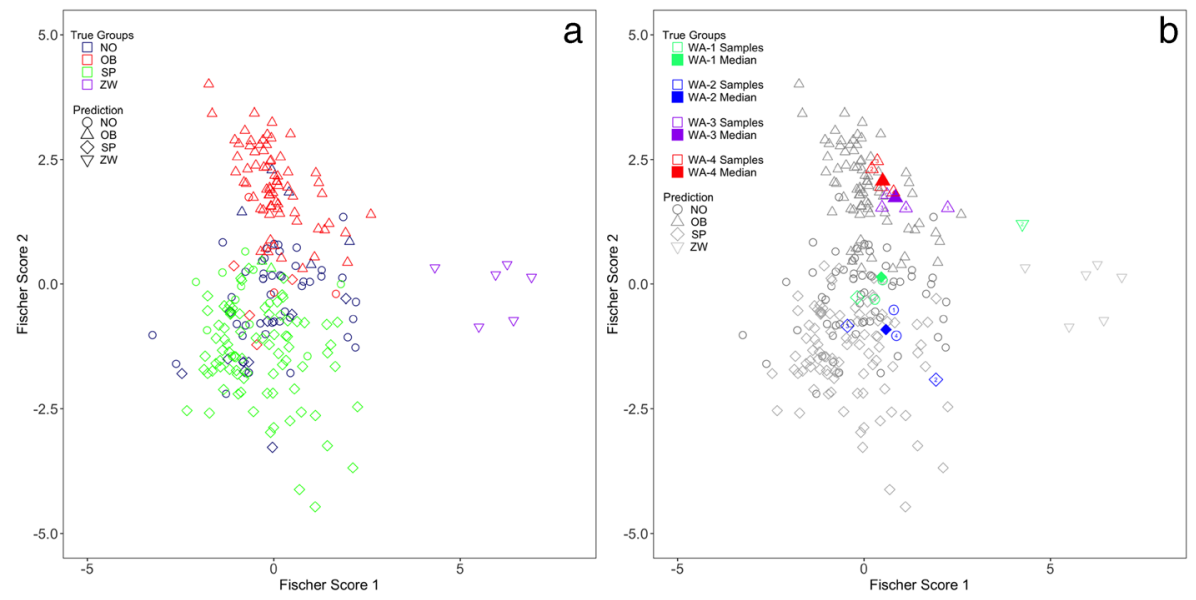

Fig. 9 Graph A shows the discriminant problem of group membership visualised by the first two Fisher scores (Johnson and Wichern 2007). This two-dimensional projection shows the best possible separation of the means for the 'control groups' based on the training data (i.e. Campanian flint types; NO, Nouvelles; OB, Obourg; SP, Spiennes; ZW, Zeven Wegen). DA for the training data yields a good separation in relation with a very high probability of group integrity, as shown by the classifications of the training data. Graph B shows the projection of the test data into the same coordinate system as the control groups. DA using trace element data to establish group membership for each individual archaeological sample reveals that the four artefacts made of black flint from Walou Cave (WA 1-4) fall well within the variability range of black flint sources of the Mons Basin, Western Belgium. The symbols refer to the predicted classes, which are specified in the prediction legend. Symbol colour in the true group legend refers to the individual artefacts from which the test data derive 
Clearly, given the dearth of data on mortality profiles, seasonality and anthropogenic modifications (Simonet 1993), the role of UP foragers in structuring the faunal composition of both Aurignacian and Gravettian layers remains difficult to assess (Supplementary Information A, Sect. 4). Based on the observation that in the Aurignacian faunal record only horse (Equus caballus) and bison (Bos primigenius) remains appear to show digestion traces, Simonet concludes that, by default, the other large mammals of the assemblage including mammoth (Mammuthus primigenius), rhinoceros (Coleodonta antiquitatis), reindeer (Rangifer tarandus), red deer (Cervus elaphus) and roe deer (Capreolus capreolus), must have been the result of human hunting (Simonet 1993). Conversly, in the absence of anthropogenic marks on the few Aurignacian faunal remains from the more recent excavations (1996-2004), De Wilde claims that the role of Aurignacian hunter-gatherers in structuring the faunal assemblage must has been fairly limited (De Wilde 2011). Nevertheless, the presence of possible anthropogenic modification marks on at least one of both antler bases recovered from the Aurignacian (Fig. 8 (7)) suggests that at least part of the antler remains from the Aurignacian represent technical by-products of actual human hunting, rather than remains of prey introduced by carnivores.

Bearing in mind the aforementioned caveats, and although the relative proportions of carnivores are slightly smaller in the Gravettian than in the Aurignacian, it is worth noting that the faunal assemblages from the Aurignacian and Gravettian layers are virtually identical in terms of taxonomic composition (Supplementary Information A, Tables S3-S5). NTAXA values for herbivores in Layers CI-1 and B-5 indicate medium-range richness, with both Aurignacian and Gravettian assemblages being dominated by ungulates. Among the wide spectrum of Pleistocene mammals represented in the Aurignacian and Gravettian of Walou Cave, reindeer (Rangifer tarandus) and horse (Equus caballus), in addition to red deer (Cervus elaphus) in the Aurignacian, are the primary taxa.

Reindeer is the dominant ungulate in the Aurignacian and Gravettian assemblages (NISP $=37$ and 63, respectively), followed by horse (NISP $=8$ and 23), red deer (NISP $=17$ and 5) and bison (NISP = 4 and 5). In addition, among the herbivores there are traces of mammoth, rhinoceros, roe deer, ibex (Capra ibex), hare (Lepus europaeus), saiga antelope (Saiga tatarica) and Megaloceros (Megaloceros giganteus) (Supplementary Information A, Tables S3-S5). Comparing percentages of reindeer skeletal elements between the layers shows similar results, with reindeer remains making up over $50 \%$ of the total herbivore NISP in both assemblages. The similarity of both assemblages in terms of taxonomic richness might suggest a high degree of regularity in the locally available resources and possibly in subsistence practices during the Aurignacian and the Gravettian occupations of the cave, although herbivore diversity is clearly too restricted a focus with regard to human subsistence.

The dominance of reindeer and horse at Walou Cave is typical of the UP in Belgium (Gautier et al. 1997) as well as in the broader European context, where these species are the most regularly observed and form the highest-ranked game among the available resources in terms of costs and benefits of hunting (Boyle 2017; Verpoorte 2009). However, both Aurignacian and Gravettian periods across Europe show significant variation in terms of faunal diversity, with some sites yielding assemblages dominated by a few species only (i.e. low diversity) whilst others display clear evidence of broad and relatively evenly distributed species frequencies per site (i.e. high diversity) (Fig. 
10). We use Simpson's index as a measure of diversity, which takes into account both species richness, and an evenness of abundance among the species present (Magurran 1988). The observed overall variation might partly result from variable subsistence strategies in relation to variable climatic-palaeoenvironmental conditions towards the LGM (Boyle 2017). Taking faunal diversity as an approximation of environmental constraints, no overall decrease in species number of taxonomic richness can be observed towards the LGM, and in fact, both Aurignacian and Gravettian periods exhibit similar median values of diversity (Aurignacian-Gravettian: Mann-Whitney $U$ test, $W=846, p$ value $=0.8758$ ). Figure 10 shows that the patterning of faunal diversity at Walou Cave does not differ significantly from one assemblage to another and that Aurignacian and Gravettian faunal composition at Walou Cave is in line with the general European trend.

\section{ZooMS Results}

Due to curatorial reasons only six of ten osseous artefacts were initially sampled for powder (1: WA/2; 2: WA84/338; 3: WA/3; 4: WA86/2231; 5: WA86/2693; 6: WA/4), with the remaining four tested by a 'minimally destructive' method. Due to the poor results, three of these were later drilled (7: WA/5; 8: WA86/1951; 9: WA86/2692) and the fourth gave adequate information. All taxa identified by ZooMS for the Aurignacian or Gravettian osseous artefacts are present in the respective faunal assemblages.

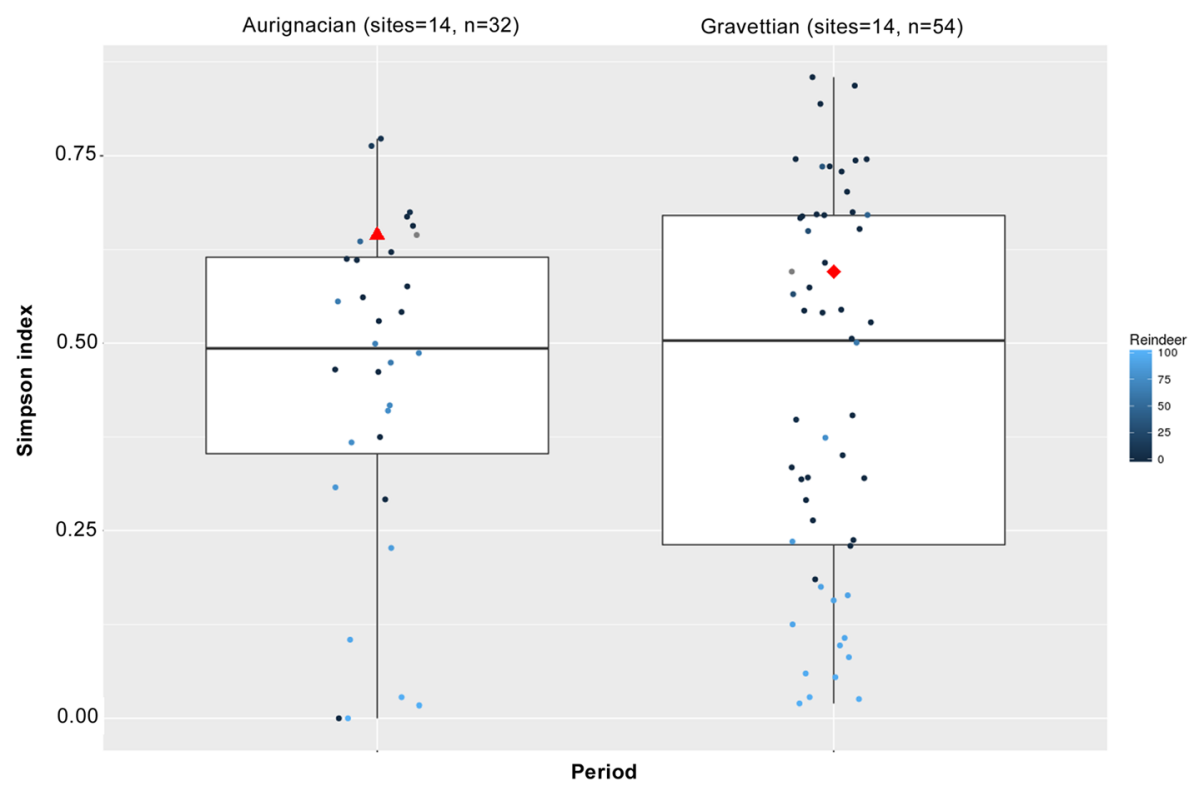

Fig. 10 Chronological distribution of Simpson diversity index values at Walou Cave compared to 28 Aurignacian and Gravettian sites (i.e. 86 faunal assemblages) across Europe (data after Boyle 1990, n.d.). Only assemblages with a sample size exceeding 50 identifiable fragments have been taken into consideration (Boyle 1990, p. 8). The Simpson's index increases as evenness increases. Faunal assemblages with a Simpson's index of less than 0.25 are almost all dominated by reindeer (see also Boyle 2017). Red symbols correspond to Aurignacian (CI-1) and Gravettian (B-5: A-D) faunas from Walou Cave. Given the small sample size, the assemblage from B-5X has not been included here 
The majority of taxonomic identifications by ZooMS resulted in matches to reindeer (Fig. 11; Table 2; Supplementary Information A, Fig. S1); out of the ten osseous artefacts analysed by ZooMS, five were identified as reindeer, thus mirroring the reindeer-dominated faunal composition for the Aurignacian and Gravettian cultural layers (i.e. samples 1: WA/2, 4: WA/2231, 5: WA/2693; 7: WA/5; 9: WA86/2692). This was supported by all peptide markers presented by Buckley et al. (2017), the most diagnostic of which being the combination of $m / z, 1166,1580$ and 3093.

Two other artefacts were identified as cervine and one as red deer. Cervine refers to anything within subfamily Cervinae (e.g. Dama/Cervus), whereas cervid refers to the family level Cervidae (including roe deer, and Alces, etc.) (Buckley et al. 2009). In the present study, one cervine identification (sample 2: WA84/338) could be confidently made, supported by markers at $\mathrm{m} / \mathrm{z} 1196,1427,1550$ and 3033 (to the presumed exclusion of fallow deer) but it should be noted here that this could be either red deer (Cervus elaphus) or megaloceros (Megaloceros sp.). Another cervid identification was possible (WA86/1951) that excludes roe deer or reindeer based on the lack of observation of peptide marker $2 \mathrm{t} 67$ (following Buckley et al. 2009). However, two of these samples failed ZooMS: one (3: WA/3) physically had a low collagen yield and gave a poor 'raw' fingerprint, whereas the other (6: WA/4) apparently had a good yield but also a poor fingerprint. The latter could be indicative of either the inappropriate measure of 'yield' or simply indicative of a level of variability within the ZooMS technique.

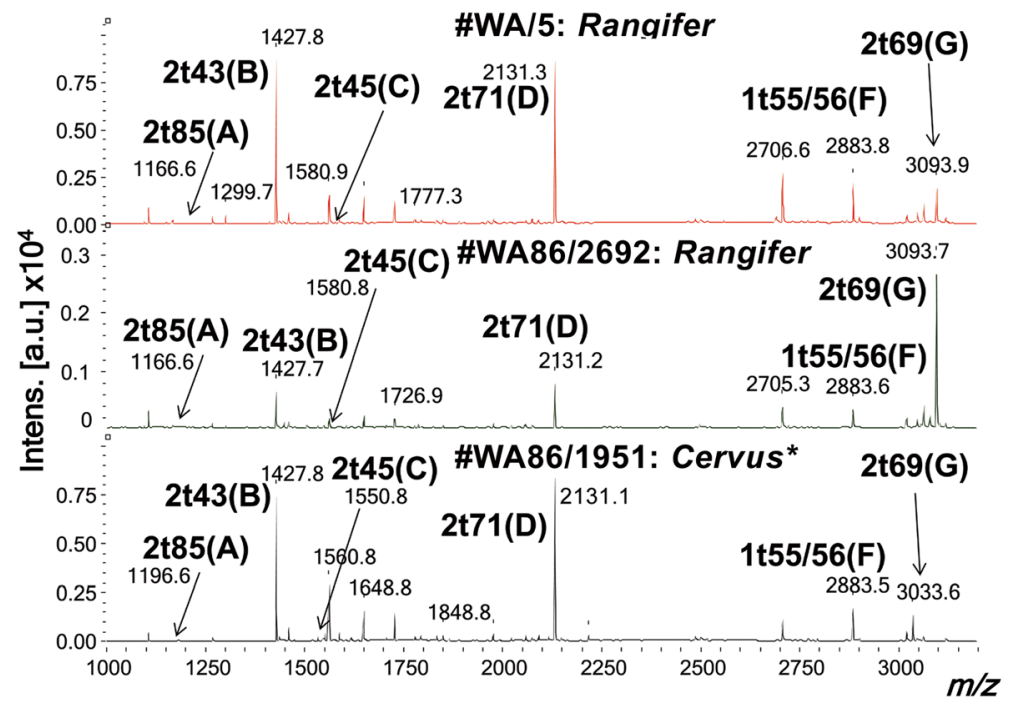

Fig. 11 MALDI-TOF mass spectrum for three osseous points from Walou Cave (IDs from top to bottom: WA/5; WA86/2692; WA86/1951). *The 'Cervus' identification under the exclusion of Dama and Megaloceros, which cannot be readily distinguished with this approach; all tagged peaks (A-G) denote sequence-matched peptides 


\section{Discussion and Perspectives}

\section{Human-Environment Interaction at Walou Cave}

In North-Western Europe, Walou Cave has yielded an unparalleled long and semicontinuous sedimentary sequence with high-precision chronostratigraphic and palaeoenvironmental detail for the Last Glacial Period. Unlike other sites in the region where chronology is based almost entirely on radiocarbon dates without reliable chronostratigraphic and palaeoenvironmental context, Walou Cave has benefitted from careful and thorough investigations of sedimentary dynamics. The multidisciplinary approach adopted in this study contributes to the development of finer-grained questions about UP adaptations across North-Western Europe prior to the LGM.

The new radiocarbon dates for the Aurignacian of Walou Cave validate the recent hypothesis that the previously available radiocarbon dates for CI-1 are underestimates (Dinnis and Flas 2016). Moreover, they are consistent with other reliable radiometric age determinations for the Belgian Aurignacian (Flas 2015; Pirson et al. 2012; Semal et al. 2013). At Spy, an osseous point fragment, likely a split-base point, has been dated to $32,830+200 /-190$ uncal BP (Semal et al. 2013); at Trou Al'Wesse, a bone tool was dated to 33,600 $\pm 550 \mathrm{BP}$ (Miller et al. 2011); and at Goyet Cave (Troisième Caverne), human remains have been dated to $30,880+170 /-160$ and $29,370+180 /-170$ (Posth et al. 2016). The Aurignacian at Walou Cave thus mirrors the increased visibility of the Aurignacian throughout North-Western Europe including Great Britain, Northern France and Germany north of the upland Mittelgebirge, in correlation with interstadial conditions of GI-8 and GI-7 (e.g. Dinnis and Flas 2016; Flas 2015; Jacobi et al. 2006; Street and Terberger 2000; Pirson et al. 2012).

Our attempts to re-date the Gravettian occupation at Walou Cave failed due to poor collagen preservation of dated samples. Based on a previously available ${ }^{14} \mathrm{C}$ date of $22,800 \pm 400$ BP on antler (Gilot 1993; Supplementary Information A, Table S1), the the Gravettian occupation (zone 1) of Walou Cave might be contemporaneous with at least some of the recently re-discovered human remains from Goyet Cave (Troisième Caverne) (Posth et al. 2016), as well as with the rich late Gravettian sites of AmiensRenancourt 1 in the Paris Basin, Grotte du Renne (level V) at Arcy-sur-Cure, and Mainz-Linsenberg in the Middle Rhineland (Higham et al. 2010; Terberger 2013; Posth et al. 2016; Paris et al. 2017).

The faunal spectrum in both Aurignacian and Gravettian assemblages at Walou Cave mirrors the faunal diversity documented at numerous other sites of this period in the broader European context, which is broadly similar between both periods. Accordingly, we suggest here that Gravettian hunter-gatherers in North-Western Europe at $50^{\circ}$ $\mathrm{N}$ latitude did not experience heightened risk as a result of declining resources and increased palaeoenvironmental variability in comparison to previous Aurignacian groups. Given our limited understanding of the taphonomic factors underlying the taxonomic composition of the faunal assemblages at Walou Cave, the basis for this assertion is admittedly rather limited. The similarity of Aurignacian and Gravettian faunas nevertheless suggests comparable food resource availability.

All osseous artefacts from Walou Cave were analysed by means of ZooMS, which proves particularly useful for articulating subsistence strategies and technological organisation. All taxa identified by ZooMS are present in the respective faunal 
assemblages and mirror the reindeer-dominated faunal composition for the Aurignacian and Gravettian cultural layers, followed by red deer and cervine. Future investigations of the faunal assemblages in terms of taphonomy and seasonality of kills will help refine our understanding of technological planning at the site, particularly with regard to the economic factors that conditioned the selection of one prey over another. Whilst ZooMS results indicate that most Aurignacian osseous points were made of reindeer antler, the attribution of two antler bases in the Aurignacian to red deer nonetheless suggests a variety of prey selection strategies.

Adopting a combined approach using ZooMS and AMS dating proved particularly useful in the case of the osseous point WA84/338 which yielded an unexpectedly young, post-LGM date of $12,640 \pm 80 \mathrm{BP}$. Bearing in mind some degree of uncertainty surrounding its reliability, this date supports the presence of a Late Glacial occupation at Walou Cave. Too young for a Gravettian context, this date might be indicative of intrusive material from the presumed Magdalenian layer (B-4) on top of Gravettian layer B-5, as the result of a flawed interpretation of the stratigraphy in this part of the cave during the excavations 1985-1990. Sample WA84/338 was identified as cervine, with C. elaphus or Megaloceros giganteus being the two most likely candidate species.

\section{Broader Implications}

If it is the case that changing patterns in blank production and tool design characterising the Gravettian did not coincide with a period of significant reshuffling of food resources, what then is the adaptive benefit of the reorganisation of lithic technological systems between both periods? It has been claimed that the differences between Aurignacian and Gravettian lithic and osseous technological systems are attributable to different hunting strategies in both periods, as reflected in variable tool design properties of osseous and lithic projectile implements (O'Farrell 2004). Whilst Aurignacian hunting equipment is considered to be dominated by osseous projectile points, conditioned by a need for reliability and strength for capturing a particular species (e.g. reindeer) under specific and predictable conditions, Gravettian hunting equipment conversely is dominated by lithic backed implements and is characterised by maintainability, versatility and flexibility, useful for a greater variety of dispersed and less predictable prey species (O'Farrell 2004, drawing on Bleed 1986). Unfortunately, the archaeozoological evidence to support this claim is far from being in agreement (e.g. Delpech 1983; Boyle 1990, 2017; Pike-Tay 1993; Enloe 1993), hence the link between hunting strategies and variable technological systems is tentative at best. It has been claimed at times that the emergence of Gravettian technologies was accompanied by the introduction of bow and arrow technology (Hays and Surmely 2005); however, no solid data support the appearance of bow and arrow technology in Europe prior to the LGM.

Using the increased scale of group mobility through time as a proxy for adaptation to conditions of climatic/environmental deterioration (Féblot-Augustins 2009), did Gravettian hunter-gatherers in North-Western Europe adopt different group mobility strategies to their Aurignacian counterparts? Palaeoclimate reconstructions based on the Hadley Centre global climate model (HadCM3), estimating average distance per move as a function of local mean annual temperature and annual precipitation (Hamilton et al. 2016), do not suggest any significant increase of residential mobility towards the LGM (Supplementary Information A, Sect. 5, Figs. S2-S3). This is not to say that 
Aurignacian and Gravettian groups that occupied Walou Cave necessarily had access to the same lithic raw material sources. In fact, the major Late Pleniglacial loess sedimentation that took place across North-Western, Central and Eastern Europe after $26 \mathrm{ka}$ uncal BP (Haesaerts et al. 2016) might well have affected the raw material sources to which the contemporaneous Gravettian groups had access. Using geochemical sourcing by means of LA-ICP-MS, this study objectively identifies the long-distance transport of lithic artifacts made of non-local flint across Belgium during the Aurignacian. In particular, the transport of Aurignacian artefacts made of exogenous black flint from the Mons Basin, c. $120 \mathrm{~km}$ away, likely reflects a strategy of 'provisioning individuals' (sensu Kuhn 1992). This involves foragers supplying themselves with raw material according to anticipated future needs by transporting and maintaining individuals' personal gear before discard and replacement by suitable local raw materials, in this case Lanaye flint. We interpret the absence of exogenous raw materials from the Mons Basin in the Walou Cave Gravettian as a potential consequence of the aforementioned aeolian sedimentation and resulting differential raw material access compared to the previous Aurignacian, rather than the result of differential adaptations in terms of technological planning and group mobility to conditions of climatic deterioration towards the LGM.

It is undeniable that in the Gravettian sites of Belgium and the German Rhineland there is repeated evidence for more distant social networks, notably based on the presence of molluscs coming from the Paris Basin and Mediterranean sources (Floss 1994; Moreau 2003; Terberger 2013). However, this does not imply that lithic procurement areas in the Gravettian of North-Western Europe were larger than those exploited by previous Aurignacian groups. Traditionally, inferred transfers of nonlocal raw materials for the UP of North-Western Europe rely on visual determinations. However, recent geochemical analyses fail to confirm some of these claimed longdistance transfers (Moreau et al. 2016). Thus, we strongly advocate for a reassessment of the issue of differential adaptations with regards to long-distance raw material transport in the Aurignacian and Gravettian of North-Western Europe in the light of renewed petrographical and geochemical approaches such as the one presented here.

Walou Cave provides the rare opportunity to tie together new multidisciplinary results to investigate UP adaptations to conditions of climatic downturn and global cold temperatures towards the LGM. The picture presented here by using multiple lines of evidence is not always clear, and our identification of limited differences in the predictability and availability of subsistence resources will require further investigations to falsify the hypothesis that Aurignacian and Gravettian technological systems are the result of an environmentally driven adaptive change. Rejecting environmental change as a driving mechanism of technological change has major implications regarding the costs and benefits underlying technological variability towards the LGM in North-Western Europe. In fact, Aurignacian and Gravettian technologies may offer no relative material advantage over one another, a phenomenon called 'technological equivalence' (sensu Lemonnier 1992; Kuhn 2004). Future investigations will therefore have to address the concomitant hypothesis that Gravettian technologies in fact correspond to an absolute rather than (environmentally driven) conditional improvement in adaptive characteristics, which predicts that the utility of the Gravettian technological system should be greater compared to the Aurignacian one. 
Supplementary Information The online version contains supplementary material available at https://doi.org/ 10.1007/s41982-021-00078-5.

Acknowledgements On behalf of all authors, the corresponding author states that there is no conflict of interest. This research was funded by a H2020 Marie Skłodowska-Curie Actions Individual Fellowship grant for L.M. (PALMOBI project, grant number 654927). New radiocarbon dates for Walou Cave were made possible by a NERC Radiocarbon Facility grant for L.M. (grant number NF/2016/2/12). Geochemical analyses were funded by a DM McDonald Grants and Awards Fund awarded to L.M. L.M. designed the research, assembled and wrote the paper; all co-authors contributed to edit the final manuscript. C.D. and S.P. provided contextual data on Walou Cave; L.M. and M.d.G. conducted lithic raw material survey; L.M., J.D., S.G. performed LA-ICP-MS analyses; E.G., P.F. and L.M. conducted statistical analysis of geochemical data; J.-M. C. provided original data on Gravettian fauna; L.M., K.B. and M.V.L. contextualised faunal data; L.M. and S.P. analysed the new radiometric determinations; L.M. and C.D. analysed the lithic assemblages; V.B. and L.M. conducted analysis of the osseous industry; M.B. performed ZooMS analysis; R.B. and A.M. performed palaeoclimate reconstructions. L.M. is grateful to Cécile Jungels, Fernand Collin and Marie de Selliers for access to the Walou Cave collections under best possible conditions; Nejma Goutas, Jose-Miguel Tejero, David Friesem, Bob Layton for discussions and comments on a previous draft. Thanks to Nuno Bicho and an anonymous reviewer for helpful comments.

Open Access This article is licensed under a Creative Commons Attribution 4.0 International License, which permits use, sharing, adaptation, distribution and reproduction in any medium or format, as long as you give appropriate credit to the original author(s) and the source, provide a link to the Creative Commons licence, and indicate if changes were made. The images or other third party material in this article are included in the article's Creative Commons licence, unless indicated otherwise in a credit line to the material. If material is not included in the article's Creative Commons licence and your intended use is not permitted by statutory regulation or exceeds the permitted use, you will need to obtain permission directly from the copyright holder. To view a copy of this licence, visit http://creativecommons.org/licenses/by/4.0/.

\section{References}

Andersen, K. K., Svensson, A., Johnsen, S. J., Rasmussen, S. O., Bigler, M., Rothlisberger, R., Ruth, U., Siggaard-Andersen, M.-L., Steffensen, J. P., Dahl-Jensen, D., Vinther, B. M., \& Clausen, H. B. (2006). The Greenland ice core chronology 2005, 15-42 ka. Part 1: constructing the time scale. Quaternary Science Reviews, 25, 3246-3257.

Antl-Weiser, W., Fladerer, F.A., Nigst, P.R., Verpoorte, A. (2010). Grub/Kranawetberg (Lower Austria) insights into a Gravettian micro-region in Eastern Austria. In: Christine Neugebauer-Maresch, Linda R. Owen (eds.), New aspects of the Central and Eastern European Upper Palaeolithic - methods, chronology, technology and subsistence. Mitteilungen der Prähistorischen Kommission vol. 72, Österreichische Akademie der Wissenschaften, Vienna, pp. 231-243.

Averbouh, A., Goutas, N., \& Marquebielle, B. (2016). Rod debitage by extraction: an overview of different cases identified for the Upper Palaeolithic and the Mesolithic in Europe. Quaternary International, 403, 57-67.

Beresford-Jones, D., Taylor, S., Paine, C., Pryor, A., Svoboda, J., \& Jones, M. (2011). Rapid climate change in the Upper Palaeolithic: the record of charcoal conifer rings from the Gravettian site of Dolní Vestonice, Czech Republic. Quaternary Science Reviews, 30, 1948-1964.

Bicho, N., \& Cascalheira, J. (2018). Global perspectives on the impact of drastic environmental changes in hunter-gatherer technologies. Journal of Quaternary Science, 33(3), 255-260.

Bicho, N., Cascalheira, J., \& Gonçalves, C. (2017). Early Upper Paleolithic colonization across Europe: time and mode of the Gravettian diffusion. PLOS ONE, 12(5), e0178506.

Blades, B. S. (1999). Aurignacian lithic economy and early modern human mobility: new perspectives from classic sites in the Vézère valley of France. Journal of Human Evolution, 37, 91-120.

Bleed, P. (1986). The optimal design of hunting weapons: maintainability and reliability. American Antiquity, $51,737-747$.

Bodu P., Bon F., Teyssandier N., Paris C. (2013). L'Aurignacien et les faciès à pieces carénées entre Yonne et Yvelines. In: P. Bodu, L. Chehmana, L. Klaric, L. Mevel, S. Soriano, N. Teyssandier (eds.) Le 
Paléolithique supérieur ancien de l'Europe du Nord-Ouest. Conference proceedings Sens 2009, Société Préhistorique Française (Mémoire LVI), pp. 37-60.

Bon, F., Simonnet, R., Vézian, J. (2005). L'équipement lithique des Aurignaciens à la Tuto de Camalhot. In: Jacques Jaubert, Michel Barbaza (eds.), Territoires, déplacements, mobilités, échanges pendant la préhistoire: Terre et hommes du Sud, pp. 173-185.

Bordes, J.-G., Bon, F., Le Brun-Ricalens, F. (2005). Le transport des matières lithiques à l'Aurignacien entre le Nord et le Sud de l'Aquitaine: faits attendus, faits nouveaux. In: Jacques Jaubert, Michel Barbaza (eds.), Territoires, déplacements, mobilités, échanges pendant la préhistoire: Terre et hommes du Sud, Toulouse, CTHS, pp. 185-198.

Borgia, V., Boschin, F., \& Ronchitelli, A. (2016). Bone and antler working at Grotta Paglicci (Rignano Garganico, Foggia, southern Italy). Quaternary International, 403, 23-39.

Boyle, K.V. (1990). Upper Palaeolithic Faunas from South West France: a Zoogeographic Perspective. British Archaeological Reports International Series S557, Oxford.

Boyle, K.V. (2017). The zooarchaeology of complexity and specialisation during the Upper Palaeolithic in Western Europe: changing diversity and evenness. In: Albarella, U., Russ, H., Vickers, K., Viner-Daniels, S. (eds.) The Oxford Handbook of Zooarchaeology. Oxford University Press (DOI: https://doi.org/10. 1093/oxfordhb/9780199686476.013.2).

Brandl, M., Moreau, L., Schmitsberger, O., \& Neugebauer-Maresch, C. (2015). The Southern Moravian Cherts at the Aurignacian site of Stratzing-Galgenberg, Austria. Anthropologie, 53, 181-202.

Brock, F., Higham, T., Ditchfield, P., \& Bronk Ramsey, C. (2010). Current pretreatment methods for AMS radiocarbon dating at the Oxford Radiocarbon Accelerator Unit (ORAU). Radiocarbon, 52, 103-112.

Bronk Ramsey, C., Higham, T. F. G., Bowles, A., \& Hedges, R. (2004). Improvements to the pretreatment of bone at Oxford. Radiocarbon, 46, 155-163.

Brou, L., Le Brun-Ricalens, F. (2005). Productions lamellaires et technocomplexes paléolithiques. Incidences: le Paléolithique supérieur revisité. In: Le Brun-Ricalens, F., Bordes, J.-G. \& Bon, F. (eds.), Productions lamellaires attribuées à l'Aurignacien. Chaînes opératoires et perspectives technoculturelles. $\mathrm{XIV}^{\circ}$ congrès de 1'UISPP, Session 6 - Paléolithique supérieur, Liège 2-8 Septembre 2001. ArchéoLogiques 1, Musée National d'Histoire et d'Art, Luxembourg, pp. 489-498.

Buckley, M., Collins, M., Thomas-Oates, J., \& Wilson, J. C. (2009). Species identification by analysis of bone collagen using matrix-assisted laser desorption/ionisation time-of-flight mass spectrometry. Rapid Communications in Mass Spectrometry, 23, 3843-3854.

Buckley, M., Fraser, S., Herman, J., Melton, N. D., Mulville, J., \& Pálsdottir, A. H. (2014). Species identification of archaeological marine mammals using collagen fingerprinting. Journal of Archaeological Science, 41, 631-641.

Buckley, M., Gu, M., Shameer, S., Patel, S., \& Chamberlain, A. T. (2016). High-throughput collagen fingerprinting of intact microfaunal remains; a low-cost method for distinguishing between murine rodent bones. Rapid Communications in Mass Spectrometry, 30, 805-812.

Buckley, M., Harvey, V., \& Chamberlain, A. (2017). Species identification and decay assessment of Late Pleistocene fragmentary vertebrate remains from Pin Hole Cave (Creswell Crags, UK) using collagen fingerprinting. Boreas, 46, 402-411.

Caux, S., \& Bordes, J.-G. (2016). The Grain de mil flint, a key resource from southwestern France during the Palaeolithic: characterization and determination criteria in archeological contexts. Paléo, 27, 105-131.

Clark, G.A. (2009). Accidents of history: conceptual frameworks in Paleoarchaeology. In: Camps, M., Chauhan, P. (eds.), Sourcebook of Paleolithic transitions. Methods, theories, and interpretations. Springer, Dodrecht.

Clark, P. U., Dyke, A. S., Shakun, J. D., Carlson, A. E., Clark, J., Wohlfarth, B., Mitrovica, J. X., Hostetler, S. W., \& McCabe, M. (2009). The Last Glacial Maximum. Science, 325, 710-714.

Collcutt, S.N. (1993). Physical Sedimentology of the Deposits if the Grotte Walou. In: Dewez, M. (Ed.) Recherches à la grotte Walou à Trooz (Province de Liège, Belgique): premier rapport de fouille. Société Wallonne de Palethnologie (Mémoire 7), Liège, pp. 11-22.

Cordy, J.-M. (1991). Résultats préliminaires de l'analyse des micromammifères de la grotte Walou (Trooz). Notae Praehistoricae, 10, 15-19.

Cordy, J.-M. (1993). L'interstade d'Arcy d'après les micromammifères de la couche aurignacienne de la grotte Walou à Trooz (Province de Liège, Belgique). In: Dewez, M. (Ed.) Recherches à la grotte Walou à Trooz (Province de Liège, Belgique): premier rapport de fouille. Société Wallonne de Palethnologie (Mémoire 7), Liège, pp. 37-43.

R Core Team (2017). R: a language and environment for statistical computing. R Foundation for Statistical Computing, Vienna, Austria. URL https://www.R-project.org/. 
Damblon F. (2011). Les analyses anthracologiques dans la séquence de la grotte Walou. In: Draily, C., Pirson, S., Toussaint, M. (eds.) (2011). La grotte Walou à Trooz. (Belgique): Fouilles 1996-2004. vol. 2. Les sciences de la vie et les datations. Études et documents - Archéologie, vol. 21, Namur, pp. 132-145.

Damblon, F., Court-Picon, M., Pirson, S. (2011). L'enregistrement palynologique de la séquence pléistocène et holocène de la grotte Walou. In: Christelle Draily, Stéphane Pirson, Michel Toussaint (eds.), La grotte Walou: fouilles 1996-2004. vol. 2. Les sciences de la vie et les datations. Études et documents Archéologie 21, Namur, pp. 84-129.

Davies, W., \& Hedges, R. (2008-2009). Dating a type site: fitting Szeleta Cave into its regional chronometric context. Praehistoria, 9-10, 35-45.

De Grooth, M.E.Th. (2011). Distinguishing upper cretaceous flint types exploited during the Neolithic in the region between Maastricht, Tongeren, Liège and Aachen. In: Jutta Meurers-Balke and Werner Schön (eds.), Vergangene Zeiten. Deutsche Gesellschaft für Ur-und Frühgeschichte (Archäologische Berichte 22), Bonn, pp. 107-130.

De Wilde, B. (2011). Les macromammifères pleistocènes de la grotte Walou. In: Draily, Chr., Pirson, S., Toussaint, M. (eds.) La grotte Walou à Trooz (Belgique). Fouilles de 1996 à 2004. Volume 2: Les sciences de la vie et les datations. Études et Documents (Archéologie 21), Namur, pp. 14-35.

Delpech, F. (1983). Les faunes du Paléolithique supérieur dans le Sud-Ouest de la France. Cahiers du Quaternaire 6, Éditions du CNRS, Paris, 453 p.

Demars, P.-Y., Laurent, P. (1992). Types d'outils lithiques du Paléolithique Supérieur en Europe. Cahiers du Quaterenaire No. 14, Paris.

Dewez, M. (1989). Données nouvelles sur le Gravettien de Belgique. Bulletin de la Société préhistorique française, 86, 138-142.

Dewez, M. (Ed.) (1993). Recherches à la grotte Walou à Trooz (Province de Liège, Belgique): Premier rapport de fouille. Société Wallonne de Palethnologie (Mémoire 7), Liège.

Dewez, M. (Ed.) (2008). Recherches à la grotte Walou à Trooz (Belgique). Second rapport de fouille. BAR International Series 1789, Oxford.

Dinnis, R., \& Flas, D. (2016). Trou du Renard and the Belgian Aurignacian. Proceedings of the Prehistoric Society, $82,1-25$.

Doyon, L., \& Katz Knecht, H. (2014). The effects of use and resharpening on morphometric variability of Aurignacian Antler projectile points. Mitteilungen der Gesellschaft für Urgeschichte, 23, 83-101.

Draily, C. (2011a). La grotte Walou à Trooz (Belgique): Fouilles de 1996 à 2004, Vol. 3, L'archéologie. Études et Documents - Archéologie, vol. 22, Namur.

Draily, C. (2011b). Présentation de la grotte Walou. In: Stéphane Pirson, Christelle Draily, Michel Toussaint (eds.), La grotte Walou à Trooz (Belgique): Fouilles 1996-2004. Volume 1: Les sciences de la terre. Études et documents - Archéologie, vol. 20, Namur, pp. 24-47.

Draily, C. (2011c). Industries lithiques du cycle B. In: Christelle Draily (ed.). La grotte Walou à Trooz (Belgique): Fouilles de 1996 à 2004, Vol. 3, L’archéologie. Études et Documents - Archéologie, vol. 22, Namur, pp. 182-195.

Draily, C. (2011d). Matières premières des occupations préhistoriques de la grotte Walou. In: Christelle Draily (ed.). La grotte Walou à Trooz (Belgique): Fouilles de 1996 à 2004, Vol. 3, L'archéologie. Études et Documents - Archéologie, vol. 22, Namur, pp. 206-223.

Draily, C., Pirson, S., Toussaint, M. (eds.) (2011). La grotte Walou à Trooz (Belgique): Fouilles 1996-2004, Vol. 2, Les sciences de la vie et les datations. Études et documents - Archéologie, vol. 21, Namur.

Enloe, J. (1993). Subsistence organisation in the Early Upper Paleolithic: reindeer hunters of the abri du Flageolet, Couche V. In H. Knecht, A. Pike-Tay, \& R. K. White (Eds.), Before Lascaux: The Complex Record of the Early Upper Paleolithic (pp. 101-117). Boca Raton: CRC Press.

Féblot-Augustins, J. (1997) La circulation des matières premières au Paléolithique. Université de Liège (ERAUL 75), Liège.

Féblot-Augustins, J. (2009). Revisiting European Upper Paleolithic raw material transfers: the demise of the cultural ecological paradigm. In B. Adams \& B. S. Blades (Eds.), Lithic materials and Paleolithic Societies (pp. 25-46). Chichester: Wiley-Blackwell.

Felder, W.M., Bosch, P.W. (2000). Krijt van Zuid-Limburg. Geologie van Nederland (vol. 5), Delft/Utrecht.

Fernandes, P., \& Raynal, J.-P. (2006). Pétroarchéologie du silex: un retour aux sources. Comptes Rendu Palevol, 5, 829-537.

Filzmoser, P., Hron, K., \& Templ, M. (2012). Discriminant analysis for compositional data and robust parameter estimation. Computational Statistics, 27, 585-604.

Fitzhugh, B. (2001). Risk and invention in human technological evolution. Journal of Anthropological Archaeology, 20, 125-167. 
Flas, D. (2000-2001). Étude de la continuité entre le Lincombien-Ranisien-Jerzmanowicien et le Gravettien aux pointes pédonculées septentrional. Préhistoire européenne, 16-17, 163-189.

Flas, D. (2015). The chronocultural sequence of Belgian complexes in the European Aurignacian context. In: R. White and R. Bourillon (eds.), Aurignacian Genius. Art, Technology and Society of the First Modern Humans in Europe. P@lethnology: 57-75.

Flas, D., Tartar, É., Bordes, J.-G., Lebrun-Ricalens, F., \& Zwyns, N. (2012-2013). New perspectives on the Aurignacian from Spy: lithic assemblage, osseous artefacts and chrono-cultural sequence. Anthropologica et Praehistoricae, 123, 231-255.

Fletcher, W., Sánchez Goñi, M. F., Allen, J. R. M., Cheddadi, R., Combourieu-Nebout, N., Huntley, B., Lawson, I., Londeix, L., Magri, D., Margari, V., Müller, U., Naughton, F., Novenko, E., Roucoux, K., \& Tzedakis, P. C. (2010). Millennial-scale variability during the last glacial in vegetation records from Europe. Quaternary Science Reviews, 29, 2839-2864.

Floss, H. (1994). Rohmaterialversorgung im Paläolithikum des Mittelrheingebietes. Habelt (Monographien des Römisch-Germanischen Zentralmuseums, 21), Bonn.

Fu, Q., et al. (2016). The genetic history of Ice Age Europe. Nature, 534, 200-205.

Gamble, C. S. (1999). The Palaeolithic Societies of Europe. Cambridge: Cambridge University Press.

Garrod, D. (1938). The Upper Palaeolithic in the light of recent discovery. Proceedings of the Prehistoric Society IV: 1-26.

Gautier, A., Cordy, J.-M., Straus, L. G., \& Otte, M. (1997). Taphonomic, chronostratigraphic, paleoenvironmental and anthropogenic implications of the Upper Pleistocene faunas from Le Trou Magrite, Belgium. Anthropozoologica, 25-26, 343-354.

Gilot, E. (1993). Liste des datations 14C effectuées sur du matériel de la Grotte Walou à Trooz (Province de Liège, Belgique). In: Michel Dewez (ed.) Recherches à la grotte Walou à Trooz (Province de Liège, Belgique): Premier rapport de fouille. Société Wallonne de Palethnologie (Mémoire 7), Liège, pp. 23.

Gilot, E. (1997). Index général des dates Lv, laboratoire du carbone 14 de Louvain/Louvain-la-Neuve. Studia Praehistorica Belgica 7, Liège-Leuven.

Goutas, N. (2009). Réflexions sur une innovation technique gravettienne importante: le double rainurage longitudinal. Bulletin de la Société préhistorique française, 437-456.

Goutas, N., \& Tejero, J.-M. (2016). Osseous technology as a reflection of chronological, economic and sociological aspects of Palaeolithic hunter-gatherers: examples from key Aurignacian and Gravettian sites in South-West Europe. Quaternary International, 403, 79-89.

Grayson, D. (1984). Quantitative zooarchaeology: topics in the analysis of archaeological faunas. Orlando: Academic Press.

Grayson, D. K., \& Delpech, F. (1998). Changing Diet Breadth in the Early Upper Palaeolithic of Southwestern France. Journal of Archaeological Science, 25, 1119-1129.

Gu, M., \& Buckley, M. (2018). Semi-supervised machine learning for automated species identification by collagen peptide mass fingerprinting. BMC Bioinformatics, 19, 241. https://doi.org/10.1186/s12859-0182221-3.

Haesaerts, P. (2004). Maisières-Canal (2000-2002): cadre stratigraphique. In: Rebecca Miller, Paul Haesaerts and Marcel Otte (eds.), L'atelier de taille aurignacien de Maisières-Canal. Éditions de 1'Université de Liège (E.R.A.U.L. 110), Liège, pp. 13-26.

Haesaerts, P., Damblon, F., Gerasimenko, N., Spagna, P., \& Pirson, S. (2016). The Late Pleistocene loesspalaeosol sequence of Middle Belgium. Quaternary International, 411, 25-43.

Hahn, J. (1995). Les ivoires en Allemagne: débitage, façonnage et utilisation au Paléolithique supérieur. In J. Hahn (Ed.), Le travail et l'usage de l'ivoire au Paléolithique supérieur (pp. 115-135). Istituto Poligrafico e Zecca dello Estato: Rome.

Hamilton, M. J., Lobo, J., Rupley, E., Youn, H., \& West, G. B. (2016). The ecological and evolutionary energetics of hunter-gatherer residential mobility. Evolutionary Anthropology, 25, 124-132.

Hays, M., \& Surmely, F. (2005). Réflexions sur la fonction des microgravettes et la question de l'utilisation de l'arc au gravettien ancien. Paléo, 17, 145-156.

Higham, T. F. G. (2011). European Middle and Upper Palaeolithic radiocarbon dates are often older than they look: problems with previous dates and some remedies. Antiquity, 85, 235-249.

Higham, T. F. G., Jacobi, R. M., \& Ramsey, C. (2006). AMS radiocarbon dating of ancient bone using ultrafiltration. Radiocarbon, 48, 179-195.

Higham, T. F. G., Jacobi, R. M., Julien, M., David, F., Basell, L., Wood, R., Davis, W., \& Bronk-Ramsey, C. (2010). Chronology of the Grotte du Renne (France) and implications for the context of ornaments and human remains within the Châtelperronian. Proceedings of the National Academy of Sciences of the United States of America, 107, 20234-20239. 
Higham, T., Douka, K., Wood, R., Ramsey, C. B., Brock, F., Basell, L., Camps, M., Arrizabalaga, A., Baena, J., Barroso-Ruíz, C., Bergman, C., Boitard, C., Boscato, P., Caparrós, M., Conard, N. J., Draily, C., Froment, A., Galván, B., Gambassini, P., Garcia-Moreno, A., Grimaldi, S., Haesaerts, P., Holt, B., IriarteChiapusso, M. J., Jelinek, A.,Jordá Pardo, J. F., Maíllo-Fernández, J. M., Marom, A., Maroto, J., Menéndez, M., Metz, L., Morin, E., Moroni, A., Negrino, F., Panagopoulou, E., Peresani, M., Pirson, S., de la Rasilla, M., Riel-Salvatore, J., Ronchitelli, A., Santamaria, D., Semal, P., Slimak, L., Soler, J., Soler, N., Villaluenga, A., Pinhasi, R., \& Jacobi, R. (2014). The timing and spatiotemporal patterning of Neanderthal disappearance. Nature 512 (7514), 309.

Jacobi, R. M., \& Pettitt, P. B. (2000). An Aurignacian point from Uphill Quarry (Somerset) and the earliest settlement of Britain by Homo sapiens sapiens. Antiquity, 74, 513-518.

Jacobi, R. M., Higham, T. F. G., \& Bronk Ramsey, C. (2006). AMS radiocarbon dating of Middle and Upper Palaeolithic bone in the British Isles: improved reliability using ultrafiltration. Journal of Quaternary Sciences, 21, 557-573.

Johnson, R. A., \& Wichern, D. W. (2007). Applied multivariate statistical analysis. Harlow: Pearson Prentice Hall.

Klaric, L. (2003). L'unité technique des industries à burins du Raysse dans leur contexte diachronique. Réflexions sur la diversité culturelle au Gravettien à partir des données de la Picardie, d'Arcy-sur-Cure, de Brassempouy et du Cirque de la Patrie. Thèse de doctorat de Préhistoire de l'Université de Paris I.

Klaric, L. (2008). L'industrie lithique gravettienne de la grotte Walou (couches B-5 et B-5x). In: M. Dewez (Ed.) Recherches à la grotte Walou à Trooz (Belgique). Second rapport de fouille. BAR IS 1789, Oxford, p. 11-28.

Klaric, L. (2013). Faciès lithiques et chronologie du Gravettien du sud du Bassin parisien et de sa marge sudoccidentale. In: Pierre Bodu, Laurence Chehmana, Laurent Klaric, Ludovic Mevel, Sylvain Soriano, Nicolas Teyssandier (eds.) Le Paléolithique supérieur ancien de l'Europe du Nord-Ouest. Conference proceedings Sens 2009, Société Préhistorique Française (Mémoire LVI), pp. 61-87.

Klíma, B. (1959). Zur Problematik des Aurignacien und Gravettien in Mittel-Europa. Archaeologica Austriaca, 26, 35-51.

Kozłowski, J. K. (2015). The Origin of the Gravettian. Quaternary International, 359-360, 3-18.

Kozłowski, S., Sachse-Kozlowska, E. (1993). Industrie lithique en silex de la couche C6 de la grotte Walou a Trooz (Province de Liege, Belgique). In: Michel Dewez (ed.), Recherches à la grotte Walou à Trooz (province de Liège, Belgique). Premier rapport de fouille. Liège: Sociéte Wallonne de Palethnologie (Mémoire no. 7), pp. 69-78.

Kuhn, S. L. (1992). On planning and curated technologies in the Middle Palaeolithic. Journal of Anthropological Research, 48, 185-214.

Kuhn, S. L. (2004). Evolutionary perspectives on technology and technological change. World Archaeology, $36,561-570$.

Lacarrière, J., Bodu, P., Julien, M.-A., Dumarçay, G., Goutas, N., Lejay, M., Peschaux, C., Naton, H.-G., Théry-Parisot, I., \& Vasiliu, L. (2015). Les Bossats (Ormesson, Paris basin, France): A new early Gravettian bison processing camp. Quaternary International, 359-360, 520-534.

Lemonnier, P. (1992). Elements for an Anthropology of Technology. Anthropological Papers of the Museum of Anthropology, No. 88. Ann Arbor, MI, University of Michigan.

Lengyel, G., \& Chu, W. (2016). Long thin blade production and Late Gravettian hunter-gatherer mobility in Eastern Central Europe. Quaternary International, 406, 166-173.

Magurran, A. E. (1988). Ecological diversity and its measurement. Princeton: Princeton University Press.

Martin-Fernandez, J.A., Palarea-Albaladejo, J., Olea, R.A. (2011). Dealing with zeros. In: V. PawlowskyGlahn and A. Buccianti (eds.), Compositional data analysis: theory and applications. Wiley, pp. 47-62.

Mevel, L. (2013). Les débuts du Paléolithique supérieur dans le centre et le sud du Bassin parisien: nouveaux acquis. Nouvelles problématiques, nouveaux terrains. In: Pierre Bodu, Laurence Chehmana, Laurent Klaric, Ludovic Mevel, Sylvain Soriano, Nicolas Teyssandier (eds.) Le Paléolithique supérieur ancien de l'Europe du Nord-Ouest. Conference proceedings Sens 2009, Société Préhistorique Française (Mémoire LVI), pp. 173-193.

Miller, R. (2001). Lithic Resource Management during the Belgian Early Upper Paleolithic. Effects of Variable Raw Material Context on Lithic Economy. E.R.A.U.L. 91, Liège.

Miller, R., Collin, F., Otte, M., Stewart, J. (2011). Le Trou Al'Wesse: du Moustérien au Néolithique dans la vallée du Hoyoux. In: Michel Toussaint, Kevin Di Modica, Stéphane Pirson (eds.), Le Paléolithique moyen en Belgique. Mélanges Marguerite Ulrix-Closset. Liège: Université de Liège (E.R.A.U.L. 128), pp. 335-342. 
Morala, A., Turq, A. (1991). Relations entre matières premières lithiques et technologie: l'exemple du Paléolithique entre Dordogne et Lot. In: 25 Ans d'Études Technologiques en Préhistoire. Juan-les-Pins, Éditions APDCA, pp. 159-168.

Moreau, L. (2003). Les éléments de parure au Paléolithique supérieur en Belgique. L'anthropologie, 107, 603-614.

Moreau, L. (2010). Geißenklösterle. The Swabian Gravettian in its European Context. Quartär, 57, 79-93.

Moreau, L. (2012). Le Gravettien ancien d'Europe centrale revisité: mise au point et perspectives. L'Anthropologie, 116, 609-638.

Moreau, L., Jöris, O. (2013). La fin de l'Aurignacien. Au sujet de la position chronologique de la station de plein air de Breitenbach dans le contexte du Paléolithique supérieur ancien en Europe centrale. In: Pierre Bodu, Laurence Chehmana, Laurent Klaric, Ludovic Mevel, Sylvain Soriano, Nicolas Teyssandier (eds.), Le Paléolithique supérieur ancien de l'Europe du Nord-Ouest. Conference proceedings Sens 2009, Société Préhistorique Française (Mémoire LVI), pp. 395-414.

Moreau, L., Terberger, T. (2019). Mobility and settlement systems of the Late Aurignacian period in Central Europe. Investigations at the newly discovered open-air site Friedrichsdorf-Seulberg (Hesse, Germany). In: Cyril Montoya, Jean-Pierre Fagnart and Jean-Luc Locht (eds.), Préhistoire de l'Europe du Nord-Ouest : mobilités, climats et identités culturelles. Volume 2: Paléolithique supérieur ancien, Paléolithique final, Mésolithique. XXVIIIe congrès préhistorique de France, Amiens (30 mai - 4 juin 2016). Société préhistorique française, Paris, pp. 85-96.

Moreau, L., Odar, B., Horvat, A., Higham, T., Turk, P., \& Pirkmaier, D. (2015). Reassessing the Aurignacian of Slovenia: lithic techno-economic behaviour and direct dating of osseous projectile points. Journal of Human Evolution, 78, 158-180.

Moreau, L., Brandl, M., Filzmoser, P., Hauzenberger, C., Hauzeur, A., Goemaere, E., Jadin, I., Collet, H., \& Schmitz, R. (2016). Geochemical sourcing of flint artefacts from western Belgium and the German Rhineland: testing hypotheses on Gravettian period mobility and raw material economy. Geoarchaeology: an International Journal, 31, 229-243.

Müller, U. C., Pross, J., Tzedakis, P. C., Gamble, C., Kotthoff, U., Schmiedl, G., Wulf, S., \& Christanis, K. (2011). The role of climate in the spread of modern humans into Europe. Quaternary Science Reviews, 30, 273-279.

Nigst, P.R. (2012). The Early Upper Palaeolithic of the Middle Danube Region. Leiden University Press (Studies in Human Evolution), Leiden.

O'Farrell, M. (2004). Les pointes de la Gravette de Corbiac (Dordogne) et considérations sur la chasse au Paléolithique supérieur ancien. In: Pierre Bodu and Claude Constantin (eds.) Approches fonctionnelles en Préhistoire. XXVe Congrès Société Préhistorique de France (Nanterre, 2000). Société préhistorique française (Mémoire), pp. 121-138.

Otte, M. (1979). Le Paléolithique supérieur ancien en Belgique. Bruxelles, Musées royaux d'Art et d'Histoire, Monographies d'archéologie nationale 5, $684 \mathrm{p}$.

Otte, M. (1983). Les groupes gravettiens en Europe centrale. In: Périgordien et Gravettien en Europe. IXe Congrès UISPP (Colloque XV, 1976), ERAUL 13, Liège, pp. 241-269.

Otte, M. (2013). Conclusion. In: Marcel Otte (ed.), Les Gravettiens. Éditions Errance, Paris, pp. 331-351.

Otte, M., Noiret, P. (2013). L'avènement des hommes modernes en Belgique. In: Pierre Bodu, Laurence Chehmana, Laurent Klaric, Ludovic Mevel, Sylvain Soriano, Nicolas Teyssandier (eds.), Le Paléolithique supérieur ancien de l'Europe du Nord-Ouest. Conference proceedings Sens 2009, Société Préhistorique Française (Mémoire LVI), pp. 461-472.

Paris, C., Deneuve, E., Fagnart, J.-P., Coudret, P., Antoine, P., Peschaux, C., Lacarrière, J., Coutard, S., Moine, O., \& Guérin, G. (2017). Premières observations sur le gisement gravettien à statuettes féminines d'Amiens-Renancourt 1 (Somme). Bulletin de la Société préhistorique française, 114, 423-444.

Pelegrin, J. (2000). Les techniques de débitage laminaire au Tardiglaciaire: critères de diagnose et quelques réflexions. In: Boris Valentin, Pierre Bodu and Marianne Christensen (eds.), L'Europe centrale et septentrionale au Tardiglaciaire: confrontation des modèles régionaux de peuplement. Actes de la Table-ronde internationale de Nemours (14-16 mai 1997), Nemours. Édition de l'Association pour la Promotion de la Recherche Archéologique en Île-de-France, pp. 73-86.

Pelegrin, J. (2011). Sur les débitages laminaires du Paléolithique supérieur. In: Françoise Delpech and Jacques Jaubert (Ed.), François Bordes et la Préhistoire. Colloque international François Bordes, Bordeaux 2009. Éditions du Comité des travaux historiques et scientifiques, Paris, pp. 141-152.

Pesesse, D. (2010). Quelques repères pour mieux comprendre l'émergence du Gravettien en France. Bulletin de la Société préhistorique française, 107, 465-487.

Pettitt, P. B. (2011). The Palaeolithic origins of human burial. London: Routledge. 
Pettitt, P. B., \& White, M. (2012). The British Palaeolithic: human societies at the edge of the Pleistocene World. London: Routledge.

Pettitt, P. B., Davies, W., Gamble, C. S., \& Richards, M. B. (2003). Palaeolithic radiocarbon chronology: quantifying our confidence beyond two half-lives. Journal of Archaeological Science, 30, 1685-1693.

Peyrony, D. (1933). Les industries « aurignaciennes » dans le bassin de la Vézère. Bulletin de la Société Préhistorique Française, 30, 543-559.

Pike-Tay, A. (1993). Hunting in the Upper Perigordian: a matter of strategy or expedience? In H. Knecht, A. Pike-Tay, \& R. White (Eds.), Before Lascaux: the complex record of the Early Upper Paleolithic (pp. 85101). Boca Raton: CRC Press.

Pirson, S. (2011). Contextes paléoenvironnemental et chronostratigraphique du remplissage de la grotte Walou: apport de la géologie et comparaison avec les autres disciplines. In: Stéphane Pirson, Christelle Draily, Michel Toussaint (eds.), La grotte Walou à Trooz (Belgique): Fouilles 1996-2004. Volume 1: Les sciences de la terre. Études et documents - Archéologie, vol. 20, Namur, pp. 170-201.

Pirson, S., Haesaerts, P., Court-Picon, M., Damblon, F., Toussaint, M., Debenham, N. C., \& Draily, C. (2006). Belgian cave entrance and rock-shelter sequences as palaeoenvironmental data recorders: the example of Walou cave. Geologica Belgica, 9, 275-286.

Pirson, S., Spagna, P., Baele, J.-M., Damblon, F., Gerrienne, P., Vanbrabant, Y., \& Yans, J. (2008). An overview of the geology of Belgium. Memoirs of the Geological Survey of Belgium, 55, 5-25.

Pirson, S., Draily, C., Toussaint, M. (eds.) (2011a). La grotte Walou à Trooz (Belgique): Fouilles 1996-2004. Volume 1: Les sciences de la terre. Études et documents - Archéologie, vol. 20, Namur.

Pirson, S., Damblon, F. Haesaerts, P. \& Draily, C., (2011b). Analyse des dates ${ }^{14} \mathrm{C}$ de la grotte Walou. In: Christelle Draily, Stéphane Pirson and Michel Toussaint (eds.), La grotte Walou à Trooz (Belgique): Fouilles 1996-2004. vol. 2. Les sciences de la vie et les datations. Études et documents - Archéologie, vol. 21, Namur, pp. 198-211.

Pirson, S., Flas, D., Abrams, G., Bonjean, D., Court-Picon, M., Di Modica, K., Draily, C., Damblon, F., Haesaerts, P., Miller, R., Rougier, H., Toussaint, M., \& Semal, P. (2012). Chronostratigraphic context of the Middle to Upper Palaeolithic transition: Recent data from Belgium. Quaternary International, 259, 78-94.

Posth, C., Renaud, G., Mittnik, A., Haak, W., Powell, A., \& Krause, J. (2016). Pleistocene mitochondrial genomes suggest a single major dispersal of non-Africans and a Late Glacial population turnover in Europe. Current Biology, 26, 1-7.

Rasmussen, S. O., Bigler, M., Blockley, S. P. E., Blunier, T., Buchardt, S. L., Clausen, H. B., Cvijanovic, I., Dahl-Jensen, D., Johnsen, S. J., Fischer, H., Gkinis, V., Guillevic, M., Hoek, W. Z., Lowe, J. J., Pedro, J. B., Popp, T., Svensson, A. M., Vallelonga, P., Vinther, B. M., Walker, M. J. C., Wheatley, J. J., \& Winstrup, M. (2014). A stratigraphic framework for abrupt climatic changes during the Last Glacial period based on three synchronized Greenland ice-core records: refining and extending the INTIMATE event stratigraphy. Quaternary Science Reviews, 106, 14-28.

Reimer, P. J., Bard, E., Bayliss, A., Beck, J. W., Blackwell, P. G., Bronk Ramsey, C., Buck, C. E., Cheng, H., Edwards, R. L., Friedrich, M., Grootes, P. M., Guilderson, T. P., Haflidason, H., Hajdas, I., Hatte, C., Heaton, T. J., Hoffman, D. L., Hogg, A. G., Hughen, K. A., Kaiser, K. F., Kromer, B., Manning, S. W., Niu, M., Reimer, R. W., Richards, D. A., Scott, E. M., Southon, J. R., Staff, R. A., Turney, C. S. M., \& van der Plicht, J. (2013). IntCal13 and Marine13 radiocarbon age calibration curves 0-50,000 years cal BP. Radiocarbon, 55, 1869-1887.

Robinson, E., Sellet, F. (eds.) (2018). Lithic technological organization and paleoenvironmental change.Global and diachronic perspectives. Springer (Studies in Human Ecology and Adaptation), Cham.

Semal P., Hauzeur A., Rougier H., Crevecoeur I., Germonpré M., Pirson S., Haesaerts P., Jungels C., Flas D., Toussaint M., Maureille B., Bocherens H., Higham T., van der Plicht J. (2013). Radiocarbon dating of human remains and associated archaeological material. In: Hélène Rougier and Patrick Semal (eds.), Spy cave. 125 years of multidisciplinary research at the Betche aux Rotches (Jemeppe-sur-Sambre, Province of Namur, Belgium). Anthropologica et Præhistorica 123, Bruxelles, pp. 331-356.

Simon, U., Händel, M., Einwögerer, M., \& Neugebauer-Maresch, C. (2014). The archaeological record of the Gravettian open air site Krems-Wachtberg. Quaternary International, 351, 5-13.

Simonet, P. (1993). La grande faune de la couche aurignacienne de la grotte Walou à Trooz (Province de Liège, Belgique): Étude préliminarie. In: Michel Dewez (ed.), Recherches à la grotte Walou à Trooz: Premier rapport de fouille. Société Wallonne de Palethnologie (Mémoire 7), Liège, pp. 51-58.

Sonneville-Bordes, D. (d.). (1963). Upper Paleolithic cultures in Western Europe. Science, 142, 347-355.

Stewart, J.R., Parfitt, S.A. (2011). Late Quaternary environmental change at Walou Cave: evidence from a preliminary analysis of the small mammals. In: Christelle Draily, Stéphane Pirson and Michel Toussaint 
(eds.), La grotte Walou: fouilles 1996-2004. vol. 2. Les sciences de la vie et les datations. Études et documents - Archéologie 21, Namur, pp. 38-59.

Stewart, J. R., Lister, A. M., Barnes, I., \& Dalén, L. (2010). Refugia revisited: individualistic responses of species in space and time. Proceedings of the Royal Society B, 277, 661-671.

Street, M., Terberger, T. (2000). The German Upper Palaeolithic 35,000-15,000 bp. New dates and insights with emphasis on the Rhineland. In: Wil Roebroeks, Margareta Mussi, Jirí Svoboda and Kelly Fennema (eds.), Hunters of the Golden Age: the Mid Upper Palaeolithic of Eurasia 30,000-20,000 bp, Leiden, Analecta Praehistorica Leidensia, 31, pp. 281-298.

Svoboda, J. (2007). On modern human penetration to Northern Eurasia: the multiple advances hypothesis. In: Paul Mellars, Katherine Boyle, Ofar Bar-Yosef and Chris Stringer (eds.), Rethinking the human revolution. New behavioural and biological perspectives on the origin and dispersal of modern humans. McDonald Institute Monographs, Cambridge, pp. 329-339.

Svoboda, J., Klima, B., Jarosova, L., Skrdla, P. (2000). The Gravettian in Moravia: climate, behaviour and technological complexity. In: Wil Roebroeks, Margareta Mussi, Jirí Svoboda and Kelly Fennema (eds.), Hunters of the Golden Age: the Mid Upper Palaeolithic of Eurasia 30,000-20,000 bp, Leiden, Analecta Praehistorica Leidensia, 31, pp. 197-217.

Svoboda, J., Novák, M., Sázelova, S., \& Demek, J. (2016). Pavlov I: a large Gravettian site in space and time. Quaternary International, 406, 95-105.

Tartar, É., Teyssandier, N., Bon, F., Liolios, D. (2006). Équipement de chasse, équipement domestique: une distinction efficace? Réflexion sur la notion d'investissement technique dans les industries aurignaciennes. In: L. Astruc, F. Bon, V. Léa, P.-Y. Milcent and S. Philibert (eds.), Normes techniques et pratiques sociales. De la simplicité des outillages pré- et protohistoriques. XXXVIe rencontres internationales d'Archéologie et d'Histoire d'Antibes. Antibes, Éditions APDCA, pp. 107-117.

Tejero, J.-M. (2014). Towards complexity in osseous raw material exploitation by the first anatomically modern humans in Europe: Aurignacian antler working. Journal of Anthropological Archaeology, 36, 72-92.

Tejero, J.-M. (2016). Spanish Aurignacian projectile points: an example of the first European Paleolithic hunting weapons in osseous materials. In: Langley, M.C. (Ed.) Osseous projectile weaponry towards an understanding of Pleistocene cultural variability. Dordrecht, Springer (Vertebrate Paleobiology and Paleoanthropology Series), pp. 55-69.

Tejero, J.-M., Christensen, M., \& Bodu, P. (2012). Red deer antler technology and early modern humans in Southeast Europe: an experimental study. Journal of Archaeological Science, 39(2), 332-346.

Terberger, T. (2013). Le Dernier Maximum glaciaire entre le Rhin et le Danube, un réexamen critique. In: Pierre Bodu, Laurence Chehmana, Laurent Klaric, Ludovic Mevel, Sylvain Soriano, Nicolas Teyssandier (eds.) Le Paléolithique supérieur ancient de l'Europe du Nord-Ouest. Conference proceedings Sens 2009, Société Préhistorique Française (Mémoire LVI), pp. 415-443.

Todorov, V., \& Filzmoser, P. (2009). An object oriented framework for robust multivariate analysis. Journal of Statistical Software, 32, 1-47.

Toussaint, M. \& Pirson, S. (2007). Aperçu historique des recherches concernant l'Homme préhistorique dans le karst belge aux XIXe et XXe siècles: archéologie, géologie, paléoanthropologie, paléontologie, datations. In: Un siècle de construction du discours scientifique en Préhistoire. Société préhistorique française, Actes du colloque du centenaire, Avignon (septembre 2004), p. 25-50.

Toussaint, M., Verna, C., Le Cabec, A., Gómez-Robles, A., Draily, C., Richards, M. P., \& Pirson, S. (2017). The Late Neandertal permanent lower left third premolar from Walou Cave (Trooz, Belgium) and its context. American Journal of Physical Anthropology, 2017, 1-10. https://doi.org/10.1002/ajpa.23252.

Touzé, O. (2018). Aux prémices du Gravettien dans le Nord-Ouest européen. Étude de la production des pointes lithiques à Maisières-Canal (province de Hainaut, Belgique). Bulletin de la Société préhistorique française, 115(3), 455-495.

Touzé, O., Flas, D., \& Pesesse, D. (2016). Technical diversity within the tanged-tool Gravettian: new results from Belgium. Quaternary International, 406, 65-83.

Turmes, M. (1996). Étude des associations de microvertebrés des couches holocènes de la grotte Walou. Bulletin de la Société royale belge d'Études géologiques et archéologiques. Les Chercheurs de la Wallonie, 36, 119-140.

Turq, A. (2005). Réflexions méthodologiques sur les études de matières premières lithiques: 1 - des lithothèques au matériel archéologique. Paléo, 17, 111-132.

Valoch, K. (1981). Beitrag zur Kenntnis des Pavlovien. Archeologické Rozhledy, 33, 279-298.

Verpoorte, A. (2009). Limiting factors on early modern human dispersals: the human biogeography of late Pleniglacial Europe. Quaternary International, 201, 77-85. 
Publisher's Note Springer Nature remains neutral with regard to jurisdictional claims in published maps and institutional affiliations.

\section{Affiliations}

Luc Moreau $^{1,2} \cdot$ Christelle Draily $^{3} \cdot$ Jean-Marie Cordy $^{4} \cdot$ Katherine Boyle $^{1} \cdot$ Michael Buckley ${ }^{5}$ - Erik Gjesfjeld ${ }^{1}$ - Peter Filzmoser ${ }^{6} \cdot$ Valentina Borgia $^{1} \cdot$ Sally A. Gibson $^{7} \cdot$ Jason Day ${ }^{7} \cdot$ Robert Beyer $^{8} \cdot$ Andrea Manica $^{8} \cdot$ Marc Vander Linden $^{9}$. Marjorie de Grooth ${ }^{10}$. Stéphane Pirson ${ }^{3}$

Luc Moreau

1m704@cam.ac.uk

1 McDonald Institute for Archaeological Research, University of Cambridge, Cambridge, UK

2 ArScan, UMR 7041, Ethnologie préhistorique, MAE - Maison René Ginouvès - Archéologie \& Ethnologie, Nanterre, France

3 Agence wallonne du Patrimoine, Service public de Wallonie, Namur, Belgium

4 Liège, Belgium

5 Manchester Institute of Biotechnology, University of Manchester, Manchester, UK

6 Institute of Statistics and Mathematical Methods in Economics, Vienna University of Technology, Vienna, Austria

7 Department of Earth Sciences, University of Cambridge, Cambridge, UK

8 Department of Zoology, University of Cambridge, Cambridge, UK

9 Institute for the Modelling of Socio-Environmental Transitions, Department of Archaeology \& Anthropology, Bournemouth University, Poole, UK

10 Bad Münstereifel, Germany 